Review Article

\title{
Challenges \& Opportunities on Catalytic Conversion of Glycerol to Value Added Chemicals
}

\author{
Zaki Yamani Zakaria1,2,*, Mazura Jusoh¹, Shams Shazid Kader¹, Siti Shawalliah Idris ${ }^{3}$ \\ ${ }^{1}$ School of Chemical \& Energy Engineering, Faculty of Engineering, Universiti Teknologi Malaysia, \\ Johor Bahru, Malaysia. \\ ${ }^{2}$ Centre for Engineering Education (CEE), Universiti Teknologi Malaysia, Johor Bahru, Malaysia. \\ ${ }^{3}$ Department of Chemical Engineering, College of Engineering, Universiti Teknologi MARA,
} Shah Alam, Malaysia.

Received: 23rd March 2021; Revised: 14th May 2021; Accepted: $14^{\text {th }}$ May 2021

Available online: 28th May 2021; Published regularly: September 2021

\section{Abstract}

With the rapid expansion of biodiesel industry, its main by-product, crude glycerol, is anticipated to reach a global production of 6 million tons in 2025. It is actually a worrying phenomenon as glycerol could potentially emerge as an excessive product with little value. Glycerol, an alcohol and oxygenated chemical from biodiesel production, has essentially enormous potential to be converted into higher value-added chemicals. Using glycerol as a starting material for value-added chemical production will create a new demand on the glycerol market such as lactic acid, propylene glycol, alkyl lactate hydrogen, olefins and others. This paper briefly reviews the recent development on value-added chemicals derived from glycerol through catalytic conversion of refined and crude glycerol that have been proven to be promising in research stage with commercialization potential, or have been put in a corporate marketable production. Despite of the huge potential of products that can be transformed from glycerol, there are still numerous challenges to be addressed and discussed that include catalyst design and robustness; focus on crude or refined glycerol; reactor technology, reaction mechanism and thermodynamic analysis; and overall process commercial viability. The discussion will hopefully provide new insights on justified direction to focus on for glycerol transformation technology.

Copyright (C) 2021 by Authors, Published by BCREC Group. This is an open access article under the CC BY-SA License (https://creativecommons.org/licenses/by-sa/4.0).

Keywords: glycerol; catalytic transformation; value added chemicals; biodiesel

How to Cite: Z.Y. Zakaria, M. Jusoh, S.S. Kader, S.S. Idris (2021). Challenges \& Opportunities on Catalytic Conversion of Glycerol to Value Added Chemicals. Bulletin of Chemical Reaction Engineering \& Catalysis, 16(3), 525547 (doi:10.9767/bcrec.16.3.10524.525-547)

Permalink/DOI: https://doi.org/10.9767/bcrec.16.3.10524.525-547

\section{Introduction}

The notion of catalytic glycerol conversion to important chemicals and fuel is not new [1-3]. Catalytic conversion of glycerol to value added chemicals has emerged as another essential and potential process to be profitable [4]. This occurs in view of the abundant availability and rock

* Corresponding Author.

Email: zakiyamani@utm.my (Z.Y. Zakaria);

Telp: +607-5535553, Fax: +607-5581463 bottom price of glycerol in the market [5]. Several reactions involving the catalytic transformation of glycerol to precious chemicals, such as hydrogen [6], acrolein [7], propylene glycol [8], dihydroxyacetone [9], glycerol carbonate [10], epichlorohydrin [11], glycerol ether [12], olefins [13] and others, have been widely reported.

Glycerol is a trihydric compound of three hydroxyl groups that is used in a variety of industrial applications. Along with starch, cellulose, hemicelluloses, and other carbohydrate poly- 
mers, it is a form of monomer found in the majority of natural polyols [14]. Glycerol is primarily generated in the oil and fats industry by high-pressure splitting [15], saponification process to produce soap [16] and production of biodiesel [17]. The processing of biodiesel appeared to be the most important contributing source of glycerol among the three processes. Currently, biodiesel is made by transesterifying vegetable oils (triglycerides) with methanol, yielding $1 \mathrm{~mol}$ of glycerol per mol of triglyceride feedstock. The price of glycerol is expected to drop dramatically as biodiesel production increases, compared to the current level, which has already dropped by half in the last few years. Crude glycerol prices have plummeted, although production has risen from 1.16 to 2 Mtons in the EU alone from 2015 to 2017. By 2026 , global demand for this chemical is projected to exceed 5 Mtons [18]. The prices of glycerol are around 2000-3000 US\$ per ton [18]. Since 2001, the price of unrefined glycerol has dropped by $25-40 \%$, to $\$ 0.35 \mathrm{~kg}^{-1}$ to $\$ 0.45$ $\mathrm{kg}^{-1}$ in 2010 [19]. Glycerol surplus has risen from 200,000 tonnes in 2003 to over 2 million tonnes in 2011, with a forecast of over 6 million tonnes by 2025 [20]. Crude glycerol is the primary by-product of today's biodiesel processes, which use homogeneous acid and simple catalysis. Heterogeneous catalysis, which uses mixed oxides, simple catalysts, and enzymes, produces more pure glycerol [21].

As opposed to hydrocarbons, glycerol has the advantage of being a highly functionalized molecule that can be used as a feedstock for the manufacture of useful products. Glycerol can be biologically and chemically transformed into other useful products [22,23]. Microbial bioconversions is one of the methods for crude glycerol to convert into high value added products that could be used as either end-products or intermediates [24-26]. The use of bacteriologic transformation of glycerol has been confirmed for the manufacture of fuels and chemicals $[27,28]$, the application of cosmetics [27], polyhydroxyacanoate for medical and agricultural field [29] as well as a variety of other items for use in basic chemical applications.

Nonetheless, the ultimate issue is the feasibility of the overall process to be commercially viable. Many of the processes are not in optimum state to be invested on. Aspects such as the fundamental chemistry, catalyst design and stability, process, reactor development, modelling and simulation works are still lacking. More investigations need to be performed to seek and establish a profitable pathway for catalytic conversion of glycerol to its derivatives.
The objective of this mini review is to examine the available processes for catalytic conversion of glycerol to important chemicals with consideration of utilizing refined and crude glycerol. Associated features within the processes such as catalyst selection, process parameters, reactor selection, feasibility study and economic potential are detailed out. Finally, discussion on the challenges, opportunities and direction follow.

\section{Catalytic Conversion of Refined and Crude Glycerol to Value-added Chemicals}

The catalytic transformation of refined glycerol to value added chemicals have been explored since mid-1990s [30-34]. The research trend since then has vigorously expanded to the present time, especially with the rapid progress of the biodiesel production worldwide. Since the value of glycerol keeps declining over time, it is indeed imperative to valorise glycerol and this can be done by converting it into chemicals of higher value and importance. Table 1 and 2 tabulate several selected important chemicals that have been converted from refined and crude glycerol recently. The forthcoming discussion will be closely linked to these tables. Refined glycerol is chosen due to its purity and for investigation purposes on the feasibility of the glycerol conversion. Having less parameter (impurities in crude glycerol) to concern will enable focus on the chemistry of the catalyst, reaction, process parameters and optimization.

Glycerol carbonate is one of the important derivatives of glycerol [35] and this is reflected from its USD $\$ 3000-3400 /$ tonne price tag [36]. It has versatile reactivity due to the presence of a hydroxyl group and a 2-oxo-1,3-dioxolane group which manage to initiate enormous applications in various domains from polymers to solvents [37]. Several routes to obtain glycerol carbonate from refined glycerol include transesterification [36,38,39], carboxylation [40] and carbonylation [41]. Among cheaper options to derive glycerol carbonate is mixing it with sodium bicarbonate over natural Clinoptilolite in a $500 \mathrm{~mL}$ batch reactor. The natural Clinoptilolite was successfully upgraded to a two dimensional zeolite solid acid catalyst with properties mimicking topology of the HEU framework in a work by Mahdi et al. [40]. Effect of temperature, catalyst mass, catalyst diameter, glycerol solvent ratio, sodium bicarbonate to glycerol ratio and reaction time were evaluated comprehensively. Evidently, the optimum conditions were attained at glycerol: sodium bicarbonate: 


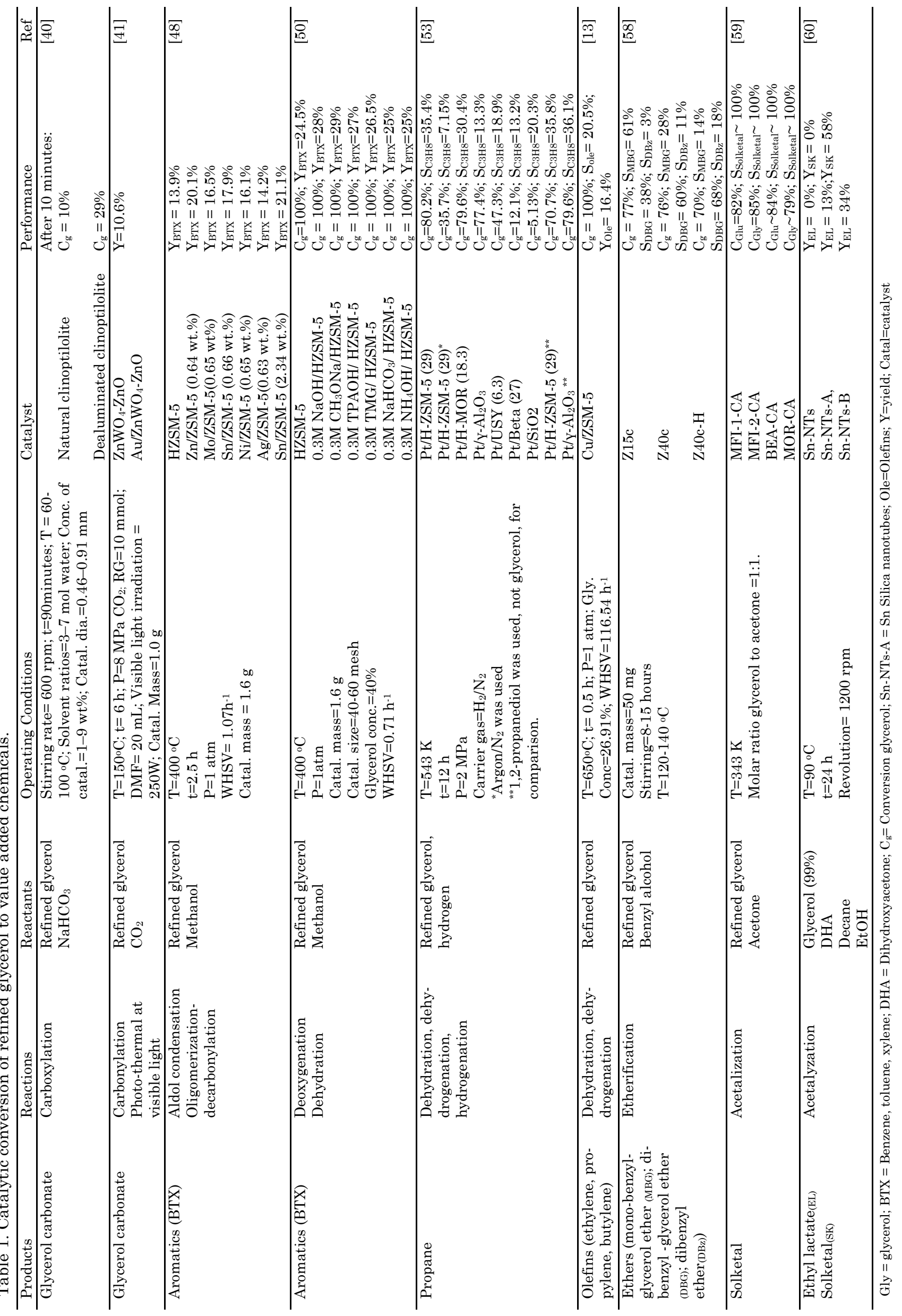


water molar ratio $3: 1: 3$. In addition, the best catalyst concentration was $9 \mathrm{wt} \%$ and diameter $0.46 \mathrm{~mm}$ was acquired at $100{ }^{\circ} \mathrm{C}$. The conversion of glycerol depended heavily on the catalyst activity in promoting reaction, as the operating temperature was just $100{ }^{\circ} \mathrm{C}$ and below. It is worth noting that this study is by far more economical than the carbonylation of glycerol to glycerol carbonate via photo thermal reaction using $\mathrm{ZnWO}_{4}-\mathrm{ZnO}$ and $\mathrm{Au} / \mathrm{ZnWO}_{4}-\mathrm{ZnO}$ catalyst [41]. The introduction of pressure, longer duration of catalytic testing and pricier catalyst may be a debatable point, but the technique employing powerful synergistic photo-thermal effect introduced a new dimension for the glycerol conversion application. This is a debut scholarly study involving thermal-driven catalytic system applied as driving force for the direct synthesis of glycerol carbonate.

Regardless of the above findings, the success of getting glycerol carbonate from crude glycerol could be more exciting as the feed is significantly cheaper, thus could reduce production cost. Qing and co-worker used a simple set up to trans-esterify crude glycerol with dimethyl carbonate over 1,8-diazabicycloundec-7-ene (DBU) catalyst and obtained crude glycerol conversion of $90 \%$ and selectivity of $89 \%$. Upon upgrading the catalyst from DBU to $\mathrm{DBU} /$ glycerol $/ \mathrm{CO}_{2}(\mathrm{DGC})$, the result obtained was not attractive. The study actually intended to utilize crude glycerol that contains DBU and DGC as impurities. In order to develop a biodiesel production technology catalyzed by DBU, the utilization of residual DBU and DGC in crude glycerol as catalysts to convert glycerol and DMC into GC under mild conditions were carried out. As far as it is concerned, this is the first study that utilizes the impurities in crude glycerol as a source of catalyst [36]. Another modern approach to derive glycerol carbonate is via a microwave assisted transesterification reaction over calcium oxide catalyst. Astonishing results were obtained upon studying various crude glycerol concentration feed over the catalyst. Ironically, crude glycerol of 70\% purity yielded the best result compared to a better quality crude and refined glycerol, as shown in Table 2. The findings pointed out that impurities in crude glycerol strangely but positively affects the transesterification of glycerol to glycerol carbonate via the utilization of microwave reactor.

Catalytic glycerol transformation to aromatics, particularly benzene, toluene and xylene (BTX) recently draws great attention [42]. Aromatics are conventionally derived from the catalytic reforming of naphtha in a petroleum re- finery [43]. Ability to decrease dependency on fossil source by glycerol transformation to BTX is deemed as very attractive. Benzene is used for the process of cumene to phenol and ethylbenzene to styrene as well as the production of cyclohexane [44]. Toluene is used in refinery streams such as gasoline blending for its octane value [45] whereas xylenes may either be used in refinery streams for gasoline blending or further separated by isomers for chemical applications [46].

Zeolites ZSM-5 is the most popular catalyst for the conversion of glycerol to aromatics [47]. Wang and co-worker modified zeolite ZSM-5 catalyst and postulated that there are two main routes in the glycerol to aromatics process. The first route is the aldol condensation of glycerol dehydration, whereby oxygen in the glycerol is removed in the form of $\mathrm{H}_{2} \mathrm{O}$, while the second path is via olefins oligomerization that originates from the decarbonylation of glycerin dewatered products, whereby oxygen is detached from the feed in the form of $\mathrm{CO}$ or $\mathrm{CO}_{2}$ [48]. He discovered that 2.34 wt\% Sn/HZSM-5, produced 21.1 wt\% BTX aromatics yield in a space of $10 \mathrm{~h}$ catalyst lifetime, which is the best screening result they gained. Further upgrading of the catalyst produced $25.2 \%$ aromatic yield. The phenomenon is explained by the incorporation of Sn cations that favourably quickens the decarbonylation steps of acetone to butene, and subsequently, assists the formation of xylene aromatics [48].

Desilication of HZSM-5 catalyst with alkali directly modifies the intramesoporosity and microporosity that can affect to aromatics formation from glycerol via consecutive deoxygenation and dehydration reactions [49]. This resulted in higher aromatics yield that not only include BTX but, trimethylbenzene and tetramethylbenzene. Notable discovery from this includes that intramesopores with size ranging between 3-5 $\mathrm{nm}$ and well-preserved parent HZSM-5 microporosity displayed better shapeselective BTX yields and gentler carbon deposition rate compared to the bigger size of $6-16$ $\mathrm{nm}$ in the glycerol transformation [50]. In a separate study, Wang investigated on the effect of acid site density on a dealuminated ZSM-5 catalyst for glycerol conversion to aromatic using liquid and gas route. A mild $\mathrm{HNO}_{3}$ treatment was applied and it preferentially eradicates the non-shape selective acid sites from HZSM-5 framework, promoting aromatics formation. Dealuminating the catalyst, on the other hand, transformed the framework tetrahedral of HZSM-5 Al species into EFAl species, promoting the decrease in the aromatics yield. 


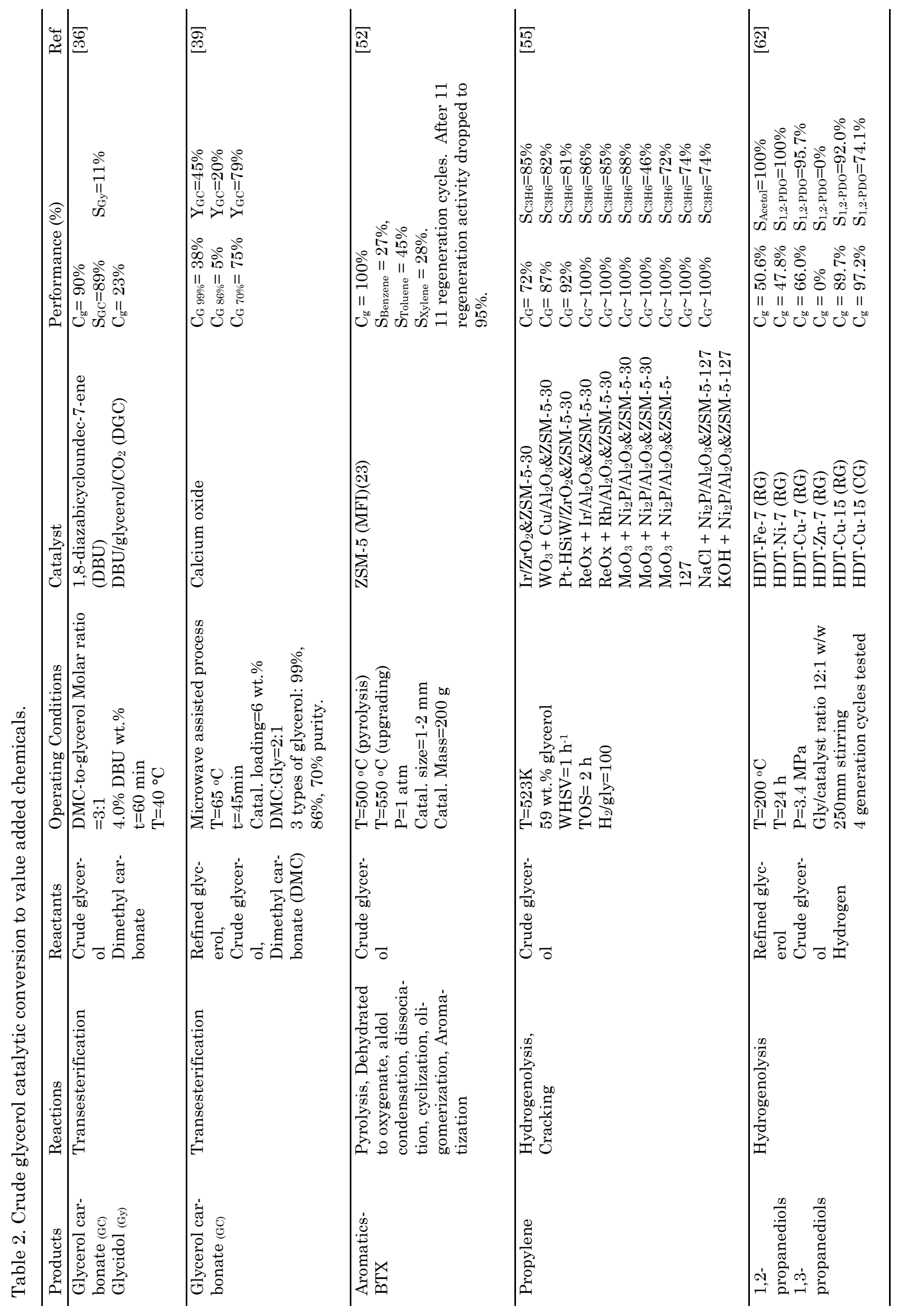



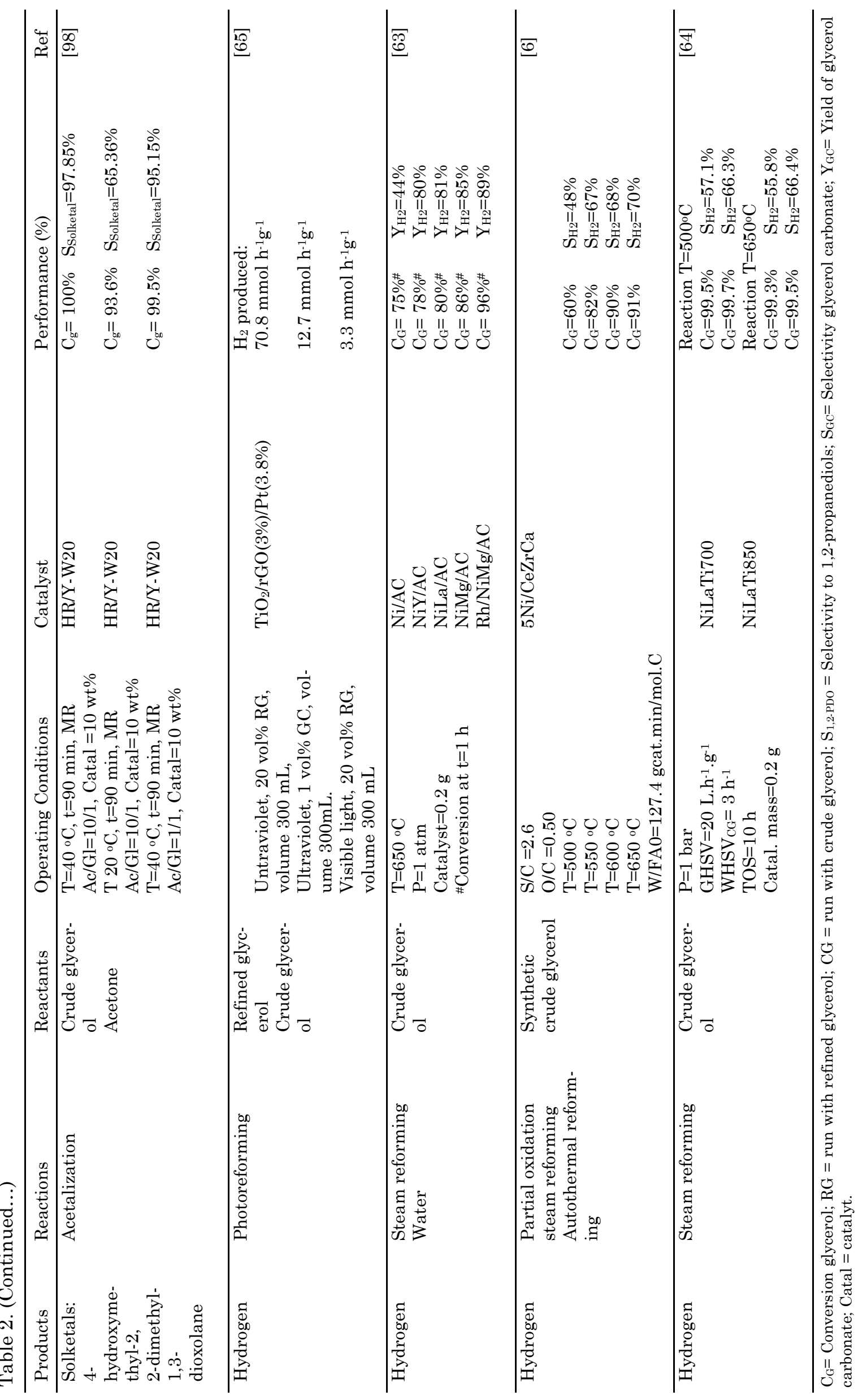
On a different note, a sequential steaming and leaching treatment created an intramesopore structure within the framework that managed to improve the life span of the HZSM- 5 catalyst up to 11.5 hours by restraining non-shape selective catalytic side reactions and coking [49]. This is an important achievement as other catalysts subjected to this process can last about 3 to 5 hours only [51].

In another research performed by Songbo, crude glycerol was used as reactant in a continuous micro reactor for the production of aromatic BTX over ZSM-5/bentonite extrudates catalyst. The important results from this study are presented in Table 2. This study is comparable to Wang's study [49] in terms of the activity of the catalyst that can remain active up to 4.7 hours, but the plus point here is that Songbo used crude glycerol [52]. The activity of the catalyst is shown to be a function of time which means the percentage BTX yield will be reduce with time due to the development of coke that covers the active site of the catalyst. Regeneration of the catalyst will recover $95 \%$ of the initial catalyst activity but after 11 consecutive regenerations step, the yield of BTX drastically dropped to $5.4 \%$. Removal of coke during catalyst regeneration was carried out using an oxidative treatment. An exchange of cations and protons from bentonite and crude glycerol plus ZSM-5 catalyst, respectively could be the reason for a permanent deactivation as the collapse of bentonite layered structure [52].

Propane, a highly important hydrocarbon source, could be obtained catalytically from glycerol via a series of dehydration, dehydrogenation, and hydrogenation reaction with hydrogen as a co-feed when subjected to various platinum impregnated zeolite catalysts. Among all catalyst, Pt/HZSM-5 showed most promising outcome with the highest glycerol conversion $(80.2 \%)$ and propane selectivity (35.4\%). Stronger acid site on the catalyst surface promotes the formation of more intermediates via the dehydration reaction compared to the steam reforming route. These intermediates are then subjected to hydrogenation reaction ought to the presence of $\mathrm{Pt} / \mathrm{H}_{2}$ to form subsequent intermediate together with methane and ethane. Repeated dehydration and hydrogenation finally leads to the formation of propane, a more stable product than the other intermediates [53]. The overall equation of the reaction is as per shown in Equation (1), where hydrogen is an essential co-feed to produce propane.

$5 \mathrm{C}_{3} \mathrm{H}_{5}(\mathrm{OH})_{3}+5 \mathrm{H}_{2}(\mathrm{~g}) \rightarrow 4 \mathrm{C}_{3} \mathrm{H}_{8}+9 \mathrm{H}_{2} \mathrm{O}+3 \mathrm{CO}_{2}$
Since hydrocarbon in the form of methane, ethane, propane can be formed as mentioned earlier, its neighbouring family, alkene (olefins) can also be formed [19]. Modified zeolite ZSM-5 based catalyst with numerous metals were synthesized and subjected to refined glycerol (30\% concentration) via steam reforming at $650{ }^{\circ} \mathrm{C}, 30$ minutes, $1 \mathrm{~atm}$ and WHSV of $107 \mathrm{~h}^{-1}$. The screening experiment revealed that Cu/ZSM-5 was the best catalyst among other metal ZSM-5 and a process optimization via response surface methodology proceeded afterwards. Optimization of the process showed that selectivity towards olefin (ethylene, propylene and butylene) was $20.5 \%$ and the yield was $16.4 \%$ [13]. The steam reforming process involves several dehydration and dehydrogenation reactions taking place on the Brönsted / Lewis acid site of Cu/ZSM-5 [54].

Propylene has proven to be able to be produced using crude glycerol as well. Various combinations of metal and acid catalysts were synthesized as per shown in Table 2. Among all, the complex $\mathrm{MoO}_{3}+\mathrm{Ni}_{2} \mathrm{P}_{2} \mathrm{Al}_{2} \mathrm{O}_{3}$ \& ZSM-530 emerged as the best catalyst, with selectivity of $88 \%$ towards propylene via a two-step systematic process-glycerol hydrogenolysis to propanol followed by propanol cracking to propylene [55]. This could be an excellent approach towards a feasible cost-effective strategy for the commercialization of bio-based propylene.

Ethers is a class of important organic compounds that contain an ether group in which an oxygen atom is connected to two alkyl or aryl groups [56]. Examples of ethers include mono-benzyl-glycerol ether, di-benzyl-glycerol ether and dibenzyl ether which could be catalytically converted from glycerol via etherification process coupled with a co-feed compound [57]. Gonzales studied the $\mathrm{Si} / \mathrm{Al}$ ratio and the role of mesoporosity in the etherification of refined glycerol with benzyl alcohol over zeolite ZSM-5 catalysts [58]. It was discovered that mono-benzyl-glycerol ether (MBG) was largely produced when low $\mathrm{Si} / \mathrm{Al}$ zeolite catalyst was used while di-benzyl-glycerol ether (DBG) was the major product over a high $\mathrm{Si} / \mathrm{Al}$ zeolite catalyst. This indicated that the selectivity towards desired specific ethers can be controlled through the adjustment of $\mathrm{Si} / \mathrm{Al}$ molar ratio of the zeolite catalyst [58].

Solketal, another important derivative from glycerol can be obtained from the acetalization reaction of glycerol with acetone over hierarchical zeolites (MFI, BEA, and MOR) at $343 \mathrm{~K}$ using a 1:1 molar. MFI hierarchical zeolites gave the best glycerol conversion and nearly 
$100 \%$ selectivity to 4-hydroxymethyl-2 and 2 dimethyl-1,3-dioxolane, both that are known as solketal. This occurred due to the convenient access of reagents to the active sites because of the establishment of mesopores structure that appeared from the desilication of the microporous zeolites [59].

Solketal can also be produced via a highly active nanotube where $\mathrm{Sn}$ is isomorphically substituted inside the Silica framework. The $\mathrm{Sn} /$ silica nanotubes efficiently catalysed the conversion of dihydroxyacetone to ethyl lactate and the transformation of glycerol to solketal [60]. This result is attributed to the improved accessibility of the active sites ascribed to tubular morphology and to the proper combination of acid sites [60]. The active sites are imperative as it hosts numerous types of Bronsted acid on the catalyst surface active site which is vital for glycerol acetalization with co-feed acetone [61]. Manjunathan stressed that strong to weak acidity available in the catalyst correlates to the yield of solketals [61].

Glycerol can be catalytically transformed into 1,2-propanediols and 1,3-propanediols via hydrogenolysis process over various modified metal hydrotalcites. In a work by Lopez et al., initially, all catalysts were screened using refined glycerol. The best catalyst, HDT-Cu, was used for further testing of hydrogenolysis with crude glycerol and percentage yield for 1,2propanediols obtained was $74.1 \%$ when the crude glycerol purity used was $62 \%$. This result was obtained when co-feeding the reaction with hydrogen at pressure $=3.4 \mathrm{MPa}$, temperature $=$

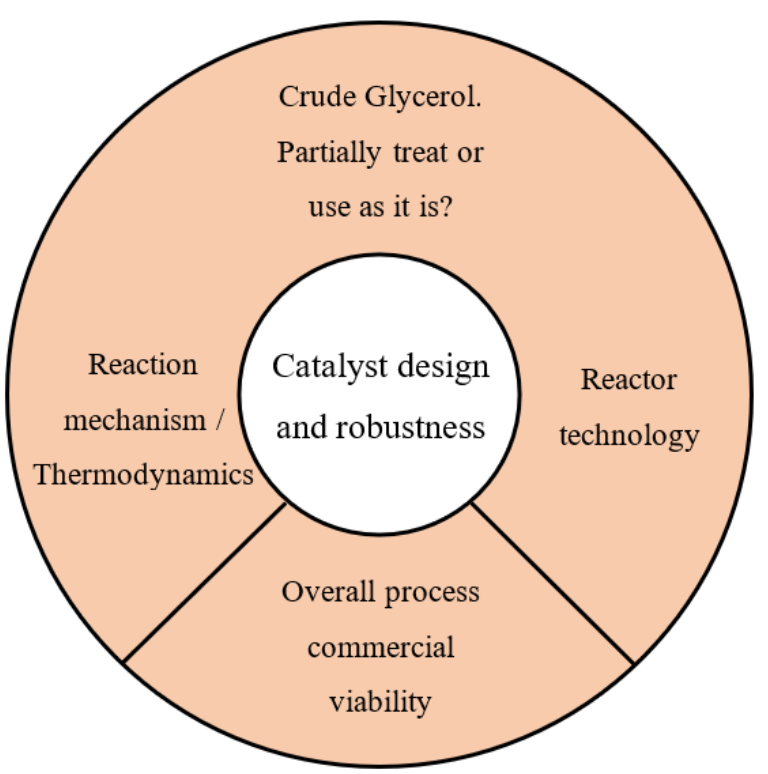

Figure 1. Challenges to be dealt with for catalytic conversion of glycerol to value-added chemicals.
$200{ }^{\circ} \mathrm{C}$ in a one day reaction. Regeneration study conducted showed that the catalyst can be used up to 4 times before the activity sharply drops [62].

Hydrogen is well known to be attained from glycerol via various reforming processes. A few recent researches utilized crude glycerol for steam reforming [63], partial oxidation steam reforming [64], photo reforming [65] and autothermal reforming [6], as described in Table 2. The glycerol photo reforming offers several advantages such as the utilization of natural free light to excite the reaction and the novel $\mathrm{TiO}_{2} / \mathrm{rGO} / \mathrm{Pt}$ catalyst for the production of hydrogen. However, the amount of hydrogen produced from the photo reforming reaction is too minute, which means there are plenty of opportunities for this research to be further developed. Nevertheless, most of the hydrogen derived from glycerol via the reforming processes display encouraging results. But the main problem lies in the life span of the catalyst because it deactivates rapidly upon a mere few hours of reaction. This is indeed the main challenge for hydrogen production from catalytic transformation of refined and crude glycerol.

\section{Challenges of Catalytic Conversion of Glycerol}

The transformation of glycerol (crude or pure condition) to value added chemicals is not easy as it sounds. There are numerous parameters that need to be considered, optimized and obliged. Even though vigorous researches have been conducted since the past decade, overall yield of value added products are still yet to reach pilot or commercial scale accept for few chemicals like epichlorohydrine (ECH) and glycerol carbonate. These are the main challenges that need to be addressed. Subsequently there will be opportunity for improvement of the process so we can head towards the correct direction.

There are several areas that can be focused to rapidly improve the transformation of glycerol to value added chemicals (Figure 1). A significant challenge falls in the decision to select between the utilization of crude or refined glycerol. Both has its own pro and cons. Obviously opting for crude glycerol will be economical on the front end but more complex and costly during reaction and separation stage. Hence, massive research opportunities to seek for a proven reaction or process that can utilize crude glycerol are openly available.

One of the prime areas to improve is the catalyst design and robustness. The catalyst design will have to consider whether crude or 
refined glycerol is employed. The physicochemical properties of the catalyst and its reactivity during reaction will affect the rate of deactivation. Hence, this is the reason main focus should be driven to catalyst design. The reactor technology will also be the next issue to be concentrated on. Different value added chemicals require different processes and reactors. One of the lacking elements for the glycerol conversion research is that, less attention are given on the reaction mechanism and thermodynamic modeling of a particular reaction. This indicates that less fundamental reaction and thermodynamic aspects are comprehended. Lacking in this area will halt the progression of upcoming development. Subsequent sub-sections will detail out all points revealed above.

3.1 Catalytic Crude Glycerol Utilization - Partially Treat or Use as It Is?

Distinctive challenges can be viewed from the catalytic transformation of glycerol to value added chemicals. These thermochemical con-

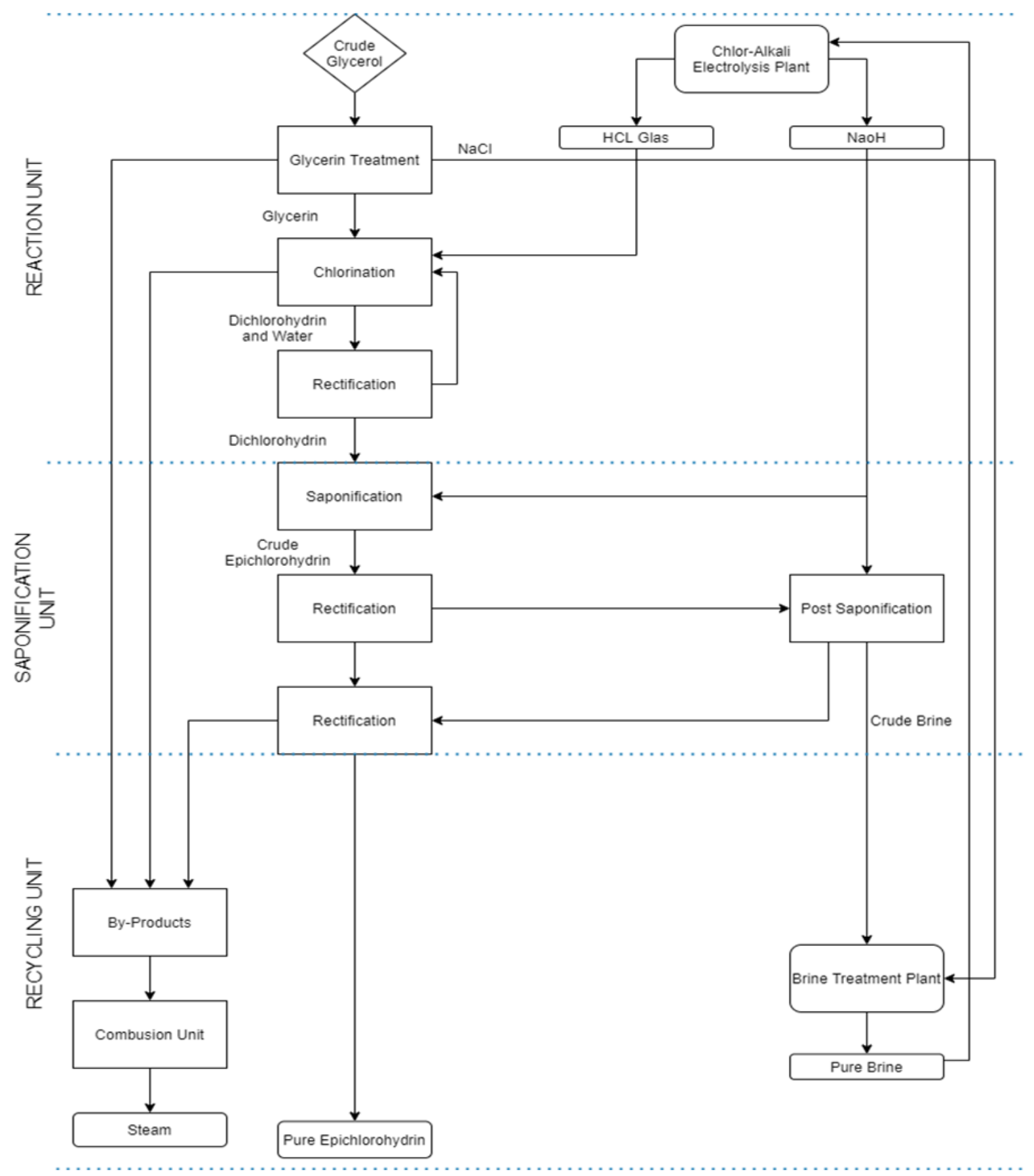

Figure 2. Process overview of Solvay ECH plant showing that crude glycerol needs to undergo treatment prior to further processing [69]. 
version pathways presently are more complicated than its biochemical conversion counterpart. The price tag difference between crude and refined glycerol is enormous. The cost of crude glycerol is between $\$ 0.09$ to $\$ 0.20$ per $\mathrm{kg}$ [22]. It will cost $\$ 1000$ per $200-400$ metric tonnes to purify crude glycerol [62]. Hence, economically, it will be more alluring to utilize crude glycerol as feed, due to the cheaper feedstock. Unfortunately, impurities contained within crude glycerol are something that needs to be accepted and dealt with. The quality within the crude glycerol is very subjective and must be carefully tackled. There are two approaches that can be used which are (a) to slightly improve and control the amount of impurities in such a way that the process can accept certain level of undesired compounds; and (b) to have a technology that can directly consume the crude glycerol as it is.

Recent report suggest that the presence of impurities are acceptable for certain process and products [66]. It is hypothesized that steam reforming, dehydration and hydrogenolysis have the potential to consume crude glycerol as reactant at high temperature and pressure [11]. But this remains as a postulated idea as for now. Perchance, a minimum specification requirement for crude glycerol ought to be established for the above mentioned process. Hypothetically, water and methanol in crude glycerol as feed encourage steam reforming but other undesired impurities may contribute destructively. Linde's technology which commenced in 2009 does not directly consume crude glycerol [67]. The impure glycerol reactant is reprocessed, pyrolyzed and reformed, producing a methane-rich gas that is fed into an existing hydrogen plant for purification and liquefaction of hydrogen. The glycerine used in the process is distilled to remove water and salts before it is cracked under high temperature and pressure to produce the pyrolysis gas [68]. This evidently infers that the crude glycerol undergoes certain level of purification before being subjected as reactant to produce hydrogen.

The commercialized ECH process demonstrates similar idea that crude glycerol needs to be treated. This technology to produce ECH epicholohydrin has successfully reached the maturity and commercial viability. Companies such as Solvay and Glaconchemie, not only have the know-how on the technology but are also dedicated to produce sustainable green solvent from glycerine [69]. The ECH process as illustrated in Figure 2 shows that the crude glycerol consumed undergoes specialized treat- ment process before being sent to the subsequent chlorination stage [69]. This indicates that the crude glycerol goes through some form of purification process, presumably up to a certain purity, that involves cost which can be tolerated within the business perspective.

The crude glycerol at its original nature maybe suitable for processes such as combustion (complete oxidation), gasification (partial oxidation) and pyrolysis (thermal degradation without oxygen) where the biodiesel waste biomass can be processed right away to produce liquid bio-oil [70]. In gasification processes, crude glycerol was adopted and hydrogen was attained [71,72]. Pyrolysis on the other hand offers incredible alternative in the production of liquid bio-oil, solid char and syngas [73,74]. Pyrolysis products can be precious compounds and chemicals. Investigation conducted by Songbo et al. [52] obtained $64.0 \mathrm{wt} \%$ of liquids (aqueous and oil phases) from pyrolysis of crude glycerol with half of it constituted to BTX aromatics, which indicated that crude glycerol catalytic transformation via pyrolysis can be directed to specific desired chemicals, depending on the catalyst design. In another case, impurities in crude glycerol produce encouraging outcome towards the formation of glycerol carbonate under microwave irradiation, compared to other types of glycerol transformation processes [39]. This means that the impurities positively affect the reactions and somehow increase the product yield. However, the subsequent main struggle lies in the challenge to separate the various precious products. This will indeed be another point of important discussion.

Several chemicals such as 1,2-propanediol, acrolein, dihydroxyacetone, glyceric acid, glycerol ethers, triacetin (glycerol esters) are not yet catalytically feasible at the moment [11] regardless of the issue of utilization of original state of crude glycerol or partially purified crude glycerol. Some of the chemicals, such as acrolein, even when refined glycerol is employed as reactant, the product selectivity and yield are still unpromising [75]. Hitches in percentage product selectivity and catalyst stability must be tackled first. This will be discussed in the subsequent sub-topic of this paper.

In brief, application of crude glycerol as feed depends heavily on the process technology. Some requires some kind of partial purification for further processing. In other contexts, crude glycerol without any prior treatment, is suitable for several thermochemical processes such as pyrolysis. Precious chemicals such as syngas, bio-oil and BTX aromatics are among im- 
portant products that can be achieved from crude glycerol without prior treatment. Further research must be conducted to improve the economics of employing crude and partially treated glycerol.

\subsection{Catalyst Design and Robustness?}

To reach high yield of desired chemicals, catalyst must be accurately designed and operating conditions should be appropriately configured [76]. This is crucial to increase the lifetime and efficiency of the catalyst. The research outcomes pointed out that direct glycerol thermochemical reaction is technologically feasible but hindered by catalyst coking that will poison the catalyst [77] and ineffective catalyst regeneration [62,78]. Table 3 explains the catalytic conversion of glycerol to different chemicals which are beneficial to us. Numerous amount of studies were made by different researchers with different catalysts to produce value added chemicals.

Catalyst coking occurs when coke is formed on catalyst surface and blocks the pores that obstruct reactant contact on active sites. Coke is easily produced from consecutive oligomerization and aromatization reactions such as for acetaldehyde, acetol, acrolein, propionaldehyde, acetone and olefins $[7,64,75]$. When catalyst is poisoned, reactions that lead to the desired product and conversion would not take place. At the moment, it is still inaccurate to claim that crude glycerol contributes significantly to catalyst coking. This scenario depends on the type of glycerol catalytic transformation. Even when refined glycerol is employed, solid catalyst will deactivate and the catalyst activity could not last long [79]. Dehydration of glycerol to acrolein, for instance, witnessed a rapid catalyst deactivation although good product yield was achieved at the beginning when refined glycerol was applied [75]. Upon consuming crude glycerol, the effect is even worse as solid catalyst deactivates rapidly in the presence of impurities, organic materials and inorganic salts [11].

Hypothetically, catalyst regeneration is essentially required to ensure that the catalyst regains its activity. Hence, concerted efforts are focused on the study of catalyst regeneration [62]. Investigation of crude glycerol transformation to aromatic BTX and 1,2-propanediol displayed good catalyst activities up to 11 times [52] and 4 times [62] of catalyst reactivation, respectively. As expected, the catalyst activity dropped after that.
To overcome this, continuous catalyst regeneration or reactivation must be carried out. But for a continuous process, this is tricky and a waste of time as the reaction must be halted to give way for the catalyst reactivation. One approach to avoid ceasing the reaction process is to co-feed small amount of oxygen that can help suppress the side products and coke formation [75]. Encouraging results were reported on the conversion and selectivity, and can result in relatively longer lifespan of the catalyst [80]. Nonetheless there is no report proving that co-feeding oxygen can extend life of catalyst to more than a few days. More work should be geared up to overcome these weaknesses.

Another method that could curb the formation of coke is by raising the reaction temperature to above $650{ }^{\circ} \mathrm{C}$ as in the case of glycerol steam and dry reforming. Coke formation originates from disproportionation of $\mathrm{CO}$, methane decomposition, hydrogenation of $\mathrm{CO}_{2}$ and hydrogenation of $\mathrm{CO}$ reactions [81]. The disproportionation of $\mathrm{CO}$, also identified as Boudard reaction, has become officious at temperatures less than $1000 \mathrm{~K}$. In this reaction, formation enthalpy of $\mathrm{CO}_{2}$ is higher than $\mathrm{CO}$ but the formation entropy is lower. As a result, the overall Gibbs free energy change of formation of $\mathrm{CO}_{2}$ by oxidation is almost constant regardless of the temperature [82]. This implies that at lower temperatures the equilibrium favours exothermic $\mathrm{CO}_{2}$ and solid carbon formation. Coke formation from methane decomposition, hydrogenation of $\mathrm{CO}_{2}$ and hydrogenation of $\mathrm{CO}$ reactions are mostly unlikely for temperature above $1000 \mathrm{~K}$ because the reactions are primarily affected by equilibrium limitation [83].

Nevertheless, despite the effort to minimize coke formation via co-feeding with oxygen and manipulating reaction temperature, the fact is the catalysts are still thermally unstable and not robust yet. Hence, superior robust catalyst with longer lifespan and more attractive product selectivity must be produced. Besides ensuring catalyst to be perfectly designed to favour the desired chemical yield and able to last longer, the extreme alkalinity or acidity properties must also be carefully considered as it can cause severe corrosion in reactor [75]. This effect may not be seen in the lab scale, but can devastatingly contribute towards commercial scale as stainless steel reactors are often employed. Awareness and precaution upon using highly alkali and acidic catalyst must be taken. Reactor wall thickness must be measured periodically based on National Association of Cor- 
Table 3. Important value-added chemicals derived from catalytic conversion of glycerol.

\begin{tabular}{|c|c|c|c|c|}
\hline $\begin{array}{l}\text { Chemical } \\
\text { formula }\end{array}$ & $\begin{array}{l}\text { Chemical } \\
\text { name }\end{array}$ & $\begin{array}{l}\text { Glycerol Transfor- } \\
\text { mation Process }\end{array}$ & Name of the Catalyst & Refs. \\
\hline $\mathrm{H}_{2}$ & Hydrogen & Reforming & Ni/AC, Ni-La-Ti, & {$[63,64,99]$} \\
\hline $\mathrm{C}_{3} \mathrm{H}_{6} \mathrm{O}_{2}$ & 3-hydroxypropanal & Dehydration & Heterogeneous catalysts & {$[76,100]$} \\
\hline $\mathrm{C}_{3} \mathrm{H}_{6} \mathrm{O}_{2}$ & Hydroxyacetone & Dehydration & Heterogeneous catalysts, Au & {$[76,101]$} \\
\hline $\mathrm{C}_{3} \mathrm{H}_{6} \mathrm{O}_{3}$ & Glyceraldehyde & Oxidation & Heterogeneous catalysts & {$[11,76,102]$} \\
\hline $\mathrm{C}_{3} \mathrm{H}_{6} \mathrm{O}_{3}$ & Lactic acid & Oxidation & Bifunctionals catalyst, $\mathrm{Cu}-\mathrm{Pt} / \mathrm{AC}$ & [103-105] \\
\hline $\mathrm{C}_{3} \mathrm{H}_{4} \mathrm{O}$ & Acrolein & Dehydration & $\begin{array}{l}\text { silicoaluminophosphate SAPO- } \\
\text { 40, ZSM- } 5 \text { zeolite, MWW-type } \\
\text { catalysts, }\end{array}$ & {$[7,87,106,107]$} \\
\hline $\mathrm{C}_{3} \mathrm{H}_{4} \mathrm{O}_{2}$ & Acrylic acid & Oxidation & $\begin{array}{l}\text { ZSM-5 zeolite, mixed oxide cata- } \\
\text { lysts }\end{array}$ & {$[7,108]$} \\
\hline $\mathrm{C}_{3} \mathrm{H}_{8} \mathrm{O}_{2}$ & 1,2-propanediol & Hydrogenolysis & $\begin{array}{l}\mathrm{Cu}-\mathrm{Ni} \text {, Pt-modified Ir-ReOx/SiO2, } \\
\text { Pt/ASA, }\end{array}$ & {$[8,109-112]$} \\
\hline $\mathrm{C}_{3} \mathrm{H}_{5} \mathrm{ClO}$ & Epicholorohydrin & Halogenation & Multifunctional catalysts & {$[11,69,113,114]$} \\
\hline $\mathrm{C}_{4} \mathrm{H}_{6} \mathrm{O}_{4}$ & Glycerol carbonate & Transesterification & $\begin{array}{l}\text { Epoxide monomers, } 1,8- \\
\text { diazabicycloundec-7-ene (DBU), } \\
\text { natural clinoptilolite }\end{array}$ & {$[36,37,40,115,116]$} \\
\hline $\mathrm{C}_{3} \mathrm{H}_{6} \mathrm{O}_{2}$ & Glycidol & Transesterification* & $\begin{array}{l}\text { 1,8-diazabicycloundec-7-ene } \\
\text { (DBU) }\end{array}$ & {$[36,100,117]$} \\
\hline $\mathrm{C}_{3} \mathrm{H}_{6} \mathrm{O}_{4}$ & Glyceric acid & Oxidation & $\begin{array}{l}\text { Bi-promoted Pt/NCNT, Cu-Pt/AC, } \\
1 \% \text { Au/charcoal or } 1 \% \\
\text { Au/graphite }\end{array}$ & {$[9,38,105]$} \\
\hline $\mathrm{C}_{3} \mathrm{H}_{6} \mathrm{O}_{3}$ & Dihydroxyacetone & Oxidation & $\begin{array}{l}\mathrm{Au}, \text { Sn-silica nanotubes, Bi- } \\
\text { promoted Pt/NCNT, }\end{array}$ & {$[2,9,60,101]$} \\
\hline $\mathrm{C}_{3} \mathrm{H}_{4} \mathrm{O}_{5}$ & Tartronic acid & Oxidation & $\mathrm{Pt}, \mathrm{Bi}-\mathrm{Pt}$ & {$[32]$} \\
\hline $\mathrm{C}_{3} \mathrm{H}_{2} \mathrm{O}_{5}$ & Mesoxalic acid & Oxidation & C-Pt-Bi & [30] \\
\hline $\mathrm{C}_{3} \mathrm{H}_{4} \mathrm{O}_{3}$ & Pyruvic acid & Oxidation & $\mathrm{Pb}-\mathrm{Pt} / \mathrm{AC}$ & [118] \\
\hline $\mathrm{C}_{3} \mathrm{H}_{4} \mathrm{O}_{4}$ & $\begin{array}{l}\text { Hydroxypyruvic } \\
\text { acid }\end{array}$ & Oxidation & Bi-Pt (acidic) & [32] \\
\hline $\mathrm{C}_{3} \mathrm{H}_{6} \mathrm{O}$ & Allyl Alcohol & Hydrogenolysis & - & {$[110,119,120]$} \\
\hline $\mathrm{C}_{3} \mathrm{H}_{6} \mathrm{O}$ & Acetone & Hydrogenolysis & Heterogeneous catalysts & [76] \\
\hline $\mathrm{C}_{3} \mathrm{H}_{6} \mathrm{O}$ & Propanal & Hydrogenolysis & $\mathrm{Pd} / \mathrm{a}-\mathrm{Al}_{2} \mathrm{O}_{3}$ & [121] \\
\hline $\mathrm{C}_{3} \mathrm{H}_{8} \mathrm{O}$ & 2-Propanol & Hydrogenolysis & $\mathrm{Ni}$ & [93] \\
\hline $\mathrm{C}_{3} \mathrm{H}_{6}$ & Propylene & Hydrogenolysis & $\begin{array}{l}\mathrm{MoO}_{3} \text {-modified } \mathrm{Ni}_{2} \mathrm{P} / \mathrm{Al}_{2} \mathrm{O}_{3} \\
\text { HZSM-5, Al/ZSM-5, Ca/ZSM-5, } \\
\text { Cr/ZSM-5, Cu/ZSM-5, Li/ZSM-5, } \\
\text { Mg/ZSM-5 and Ni/ZSM-5 }\end{array}$ & {$[54,55,110]$} \\
\hline $\mathrm{C}_{3} \mathrm{H}_{8}$ & Propane & Hydrogenolysis & $\mathrm{Pt} / \mathrm{H}-\mathrm{ZSM} 5$ & {$[53]$} \\
\hline $\mathrm{C}_{4} \mathrm{H}_{8} \mathrm{O}_{2}$ & Dioxane & Condensation & - & [11] \\
\hline $\mathrm{C}_{3} \mathrm{H}_{6} \mathrm{O}_{2}$ & Dioxalane & Condensation & - & [11] \\
\hline $\mathrm{RCO}_{2} \mathrm{R}^{\prime}$ & $\begin{array}{l}\text { Glycerol esters } \\
\text { (e.g.: Monoacetin, } \\
\text { diacetin and Tri- } \\
\text { acetin) }\end{array}$ & Esterification & Heterogeneous catalysts & [3] \\
\hline $\mathrm{R}-\mathrm{O}-\mathrm{R}^{\prime}$ & $\begin{array}{l}\text { Glycerol ether } \\
\text { (e.g.: Mono-, di-, } \\
\text { tri-tertiary butyl } \\
\text { glycerol ether) }\end{array}$ & Etherification & Resin catalyst & {$[3,122]$} \\
\hline
\end{tabular}


rosion Engineers (NACE) International standards, which are briefly discussed in the subsequent section.

\subsection{Reactor Consideration?}

Selection of reactor directly correlates with the process and catalyst properties. Highly acidic or alkali catalyst may negatively affect the internal parts and wall of a steel reactor in the form of corrosion $[84,85]$. Heavy corrosion may impair the functioning of reactor parts and reduce their lifetime. This, in turn, would increase the shut-down periods of reactors for maintenance and repair work, with a corresponding rise in operating cost.

If such extreme catalyst could not be avoided, the manufacturing processes will need plastic-lined or glass-lined steel equipment for its reactors. Highly permeable chemicals, especially at high temperatures and high pressures require plastic-lined steel equipment that has a liner with the lowest permeation and diffusion rates while providing a reasonable lifetime and commercial success [86]. The CAPEX for preparing for such reactor and its related infrastructure will be tremendously high. Hence, careful consideration must be planned at the early state of research regarding the process technology, catalyst and operating process parameter.

Technology of catalytic transformation of glycerol to chemical also involves not just two or three reactors, but a number of other vessels and unit operation. The process, catalyst and product will dictate the type of reactors. Hence, study of comparison of reactor for specific process should be performed such as the one con- ducted by Nomanbhay but he only focused on glycerol pyrolysis [70]. The efforts to study available reactors for glycerol thermochemical reaction should be extended to other types of process, such as steam reforming or carboxylation.

Subsequently, process optimization of the technology involving the reactor and scaling up should be performed. Optimization is key fundamental in the way to reduce the impact of feedstock variability and impurities.

\subsection{In-depth Knowledge on Reaction Mecha- nism and Thermodynamics}

Strong and deep comprehension on what is happening in the complex reaction network of this biomass is imperative. Multiple reactions take place simultaneously in a fraction of time, some which are formed within split second and followed by a series of other reactions. Multiple products are temporarily formed and vanished to a more stable product. Henceforth, the understanding of the reaction mechanism of a process is very critical and this directly relates to the catalyst properties. A glycerol dehydration reaction direction is decided by the strength of acid as well as type of acid (Lewis or Brönsted) within the catalyst surface [76]. Products from glycerol dehydration for a steam reforming at $400{ }^{\circ} \mathrm{C}$ could be hydroxyacetone if the hydroxyl group of glycerol reacts with Lewis acid site; or 3-hydroxypropanal should hydroxyl group favours Brönsted acid site. But, it has been reported that 3-hydroxypropanal is readily converted to acrolein, a more stable compound, via subsequent dehydration reaction. Earlier before, Corma reported that glyc-

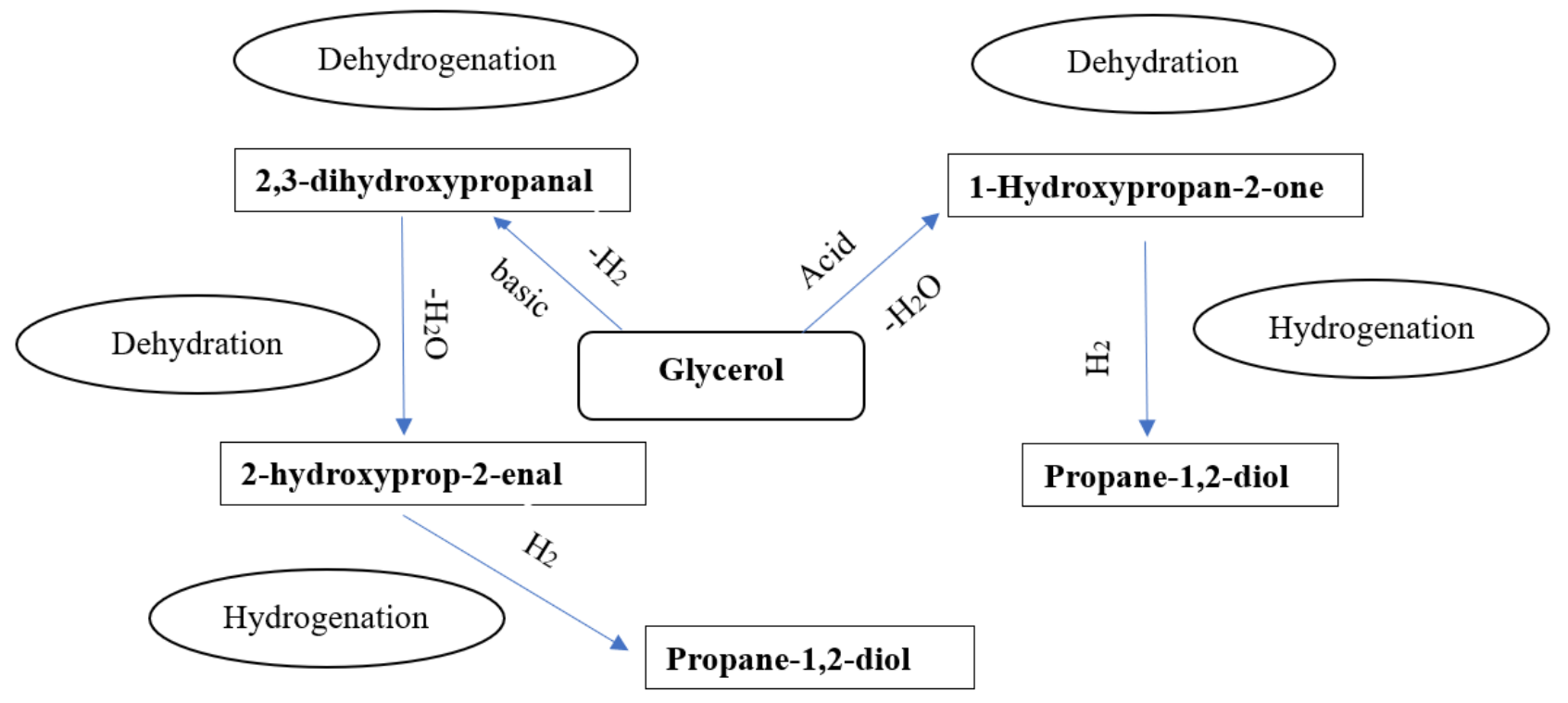

Figure 3. Reaction Mechanism for production of 1,2-Propanediol (1,2-PDO) [94]. 
erol dehydration at temperature $350{ }^{\circ} \mathrm{C}$ and $500{ }^{\circ} \mathrm{C}$ takes place in two pathways and declared that $66 \%$ will be directed to the formation of acetol and 33\% towards acrolein. Transformation to acetol and its sub products occurred due to the glycerol molecule central alcohol function removal [77]. Other complex reaction network postulations were discussed by $[22,76,87]$.

Besides reaction mechanism knowledge, thermodynamics of each reaction in the complex reaction network is substantially imperative and could provide precious information. Adhikari in his study of glycerol steam reforming to hydrogen revealed that the thermodynamics investigation heavily depends on process variables (pressure, temperature and ratio of reactants) [88]. Cheng and co-workers studied the thermodynamic analysis of glycerolsteam reforming in the presence of $\mathrm{CO}_{2}$ or $\mathrm{H}_{2}$ as carbon gasifying agents which demonstrated that existence of co-feed directly affects the product selectivities based on the temperature and pressure [89]. Other thermodynamic researches include thermodynamic feasibility of glycerol dry autothermal reforming [90], thermodynamic analysis of different carbon deposits from oxidative steam reforming of glycerol to produce hydrogen [91] as well as the thermodynamic investigation of glycerol conversion to light olefins [83]. An important point to note is that, all the thermodynamic analysis conducted was performed without catalyst. Hence, a more advanced study involving specialized catalytic thermodynamic analysis for glycerol conversion to chemicals must be developed.

Figure 3 represents the production of 1,2Propanediol (1,2-PDO) from glycerol. Under hydrogenolysis conditions, it is the most possible reaction pathway. For glycerol hydrogenolysis, metal-acid bifunctional catalysts have been identified as the most successful.

Co-etherification with isobutene and tertbutanol improves glycerol conversion. Figure 4 displays the reaction mechanism. The etherification of glycerol with isobutene or tert-butanol yields tert-Butyl glycerol ethers, which are useful fuel additives. Isobutene and glycerol both react well to the amphiphilic tert-butanol. As

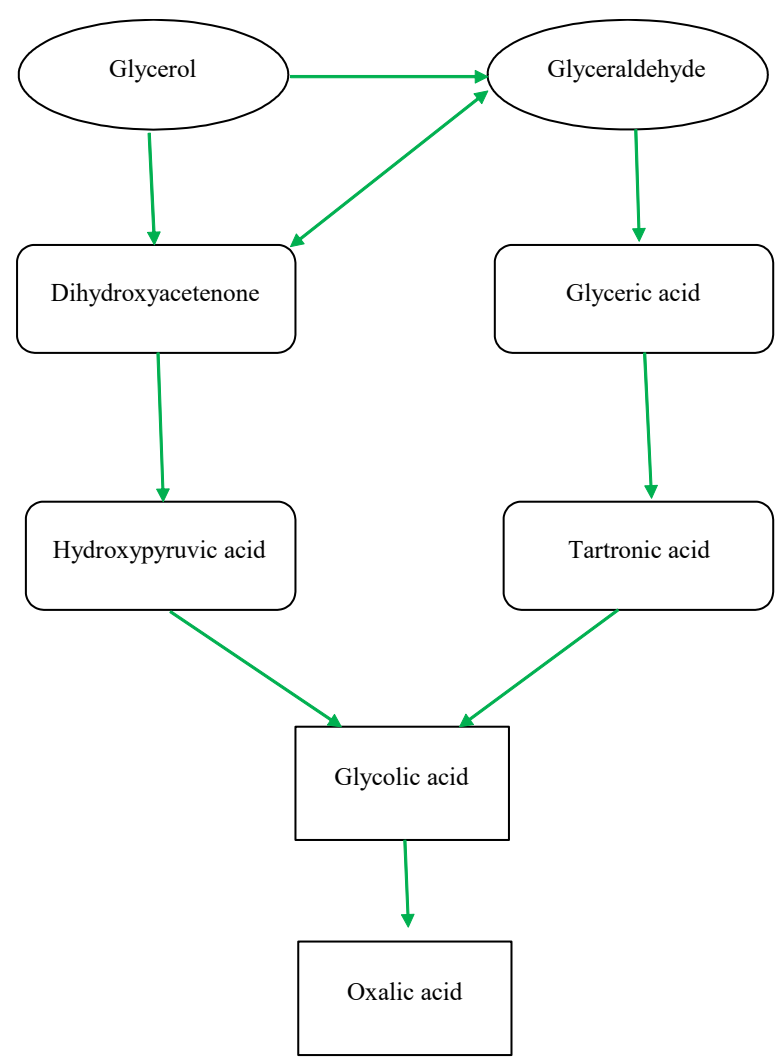

Figure 5. Reaction pathway from glycerol [96].

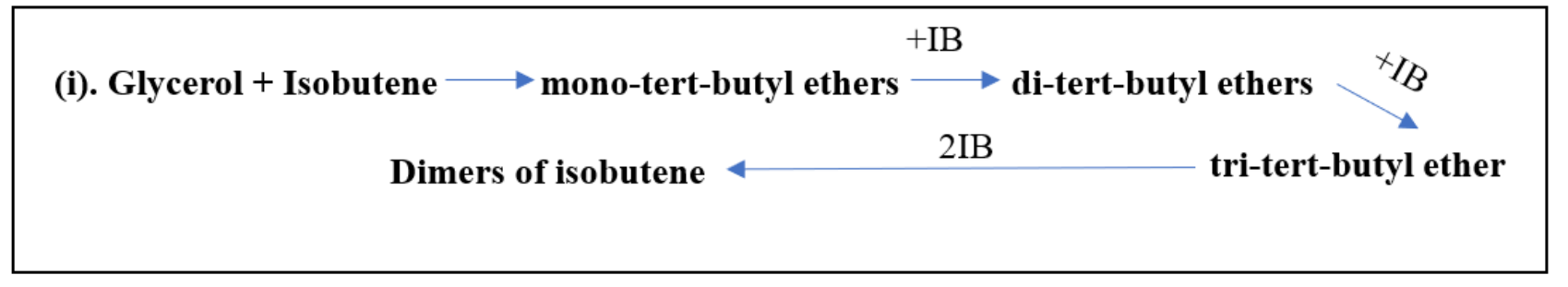

(ii). Glycerol + tert-butanol $\rightarrow$ mono-tert-butyl ethers $+\mathrm{H}_{2} \mathrm{O}$

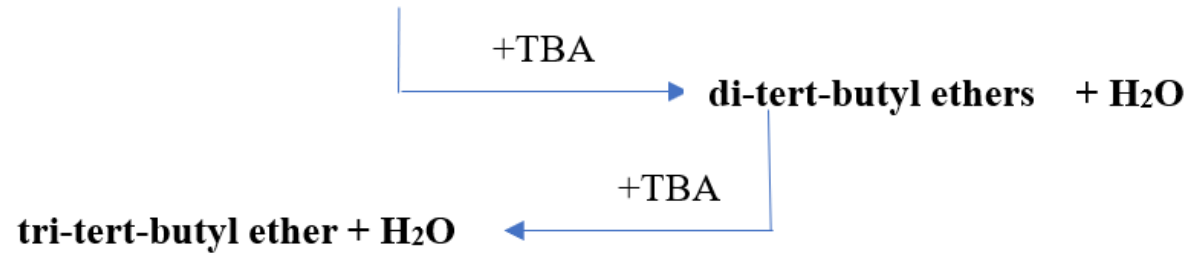

Figure 4. Reaction mechanism for glycerol etherification with isobutene and with tert-butanol [95]. 
tert-butanol is added to a glycerol-isobutene reaction, it increases the isobutene concentration in the glycerol and hence the reaction rate. In glycerol etherification, replacing a portion of tert-butanol with isobutene could transfer the reaction to polysubstituted ethers while also reducing the amount of water formed. Overall, the addition of isobutene could increase glycerol conversion and produce more polysubstituted ethers. Acid catalysts, such as resins, zeolites, and other materials, can catalyse both reaction mechanisms under identical conditions.

Alexander Luis Imbault and his co-workers studied on converting glycerol into carbonyl compounds. Figure 5 shows the pathway for conversion of glycerol. Glycerol conversion reactions in the gas phase using bifunctional hierarchical zeolite-supported bi- and tri-metallic catalysts to produce allyl alcohol was studied by Andrii Kostyniuk. Figure 6 illustrates the reaction pathway by using $\mathrm{CsFeMo/HZSM-5}$ catalysts for glycerol conversion to allyl alcohol and other reaction products. The dehydration and transition hydrogenation process was used to extract allyl alcohol directly from glycerol over the simple sites of the CsFeMo-ZSM-5 catalyst. On Lewis and Brönsted acid sites, hydroxyacetone and acrolein activity took place at the same time. It was discovered that the addition of Cs to FeMo-ZSM-5 inhibited all reactions.

In short the chemistry of glycerol conversion must be properly understood via reaction mechanism and thermodynamics feasibility. From the knowledge of this glycerol complex reaction network, catalyst can be tailor made to fulfil the demand for the desired reaction pathway.

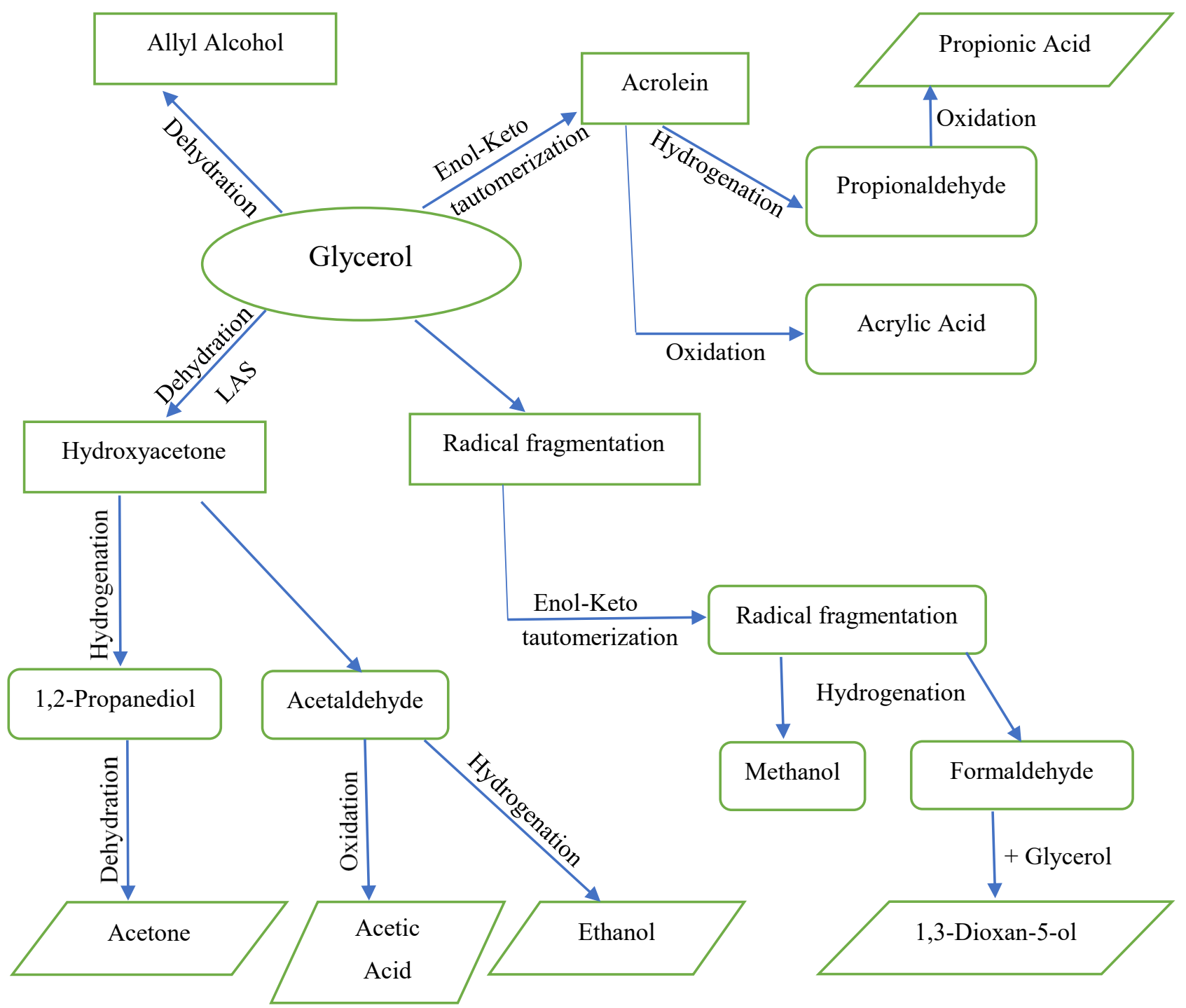

Figure 6. Reaction pathway by using CsFeMo/HZSM-5 catalysts for conversion of glycerol to other products [123] 


\subsection{Commercial Viability of the Overall Process}

All knowledge and information discussed earlier will not be sufficient to run a profitable business. The overall comparison of feasibility, cost viability, exergy for specific products and processes should be carried out. However, before a specific process is chosen, it is essential to make detailed comparison between all the available processes. A brief but good comparison of reactors for pyrolysis were carried out that include the variety of percentage product yield [70]. Although most of the comparisons dwell between lab scale researches, the input provides great indication on what really works. Most of the current methods of utilization of crude glycerol are only able to uptake small volumes of the waste glycerol and the real costs of its utilization are uncertain or not carried out. On top of that, percentage yield, the energy/mass, product/cost and others must also be considered, not to mention the recovery cost as well. The Engineering Procurement and Construction (EPC) would not be a tough task if all the above discussed aspects are well established and covered. Another perspective to consider is the exergoeconomic and exergoenvironmental of glycerol conversion into value-added chemicals. It is imperative to focus into the reactor and process development holistically. As up to this point, not much work on the exergoeconomic and exergoenvironmental of glycerol transformation have been reported, apart from that of Aghbashlo and co-workers, where they analysed the solketal synthesis via glycerol ketalization with acetone in the presence of ethanol as co-solvent and Purolite PD206 as catalyst [92].

An established chemical plant such as propylene glycol that is processed via hydrogenolysis is good because cheap catalyst is employed but at the same time there is always room for improvements, especially in the technological, energy and cost perspective. The production of propylene glycol still requires ex-situ hydrogen supply [75]. Freitas et al. investigated a continuous reaction pathway, without external hydrogen, for glycerol transformation to propylene glycol via dehydration to acetol, with simultaneous reforming to $\mathrm{H}_{2}$ and $\mathrm{CO}_{2}$. The $\mathrm{H}_{2}$ formed from the reactions itself was used for the hydrogenation of acetol to propylene glycol using CuNi/Al ${ }_{2} \mathrm{O}_{3}$ and $\mathrm{CuNi} / \mathrm{ZSM}-5$ [8]. In a separate study, Maglinao and co-workers converted crude glycerol to propylene glycol in a batch pressure reactor and Raney nickel catalyst, without having to supply hydrogen. Highest propylene glycol of about 33\% was attained when $6 \mathrm{wt} \%$ of nickel based catalyst was used at glycerol : water ratio of 1 to 1 for 45 minutes at $230{ }^{\circ} \mathrm{C}$ [93].

Catalytic reactor processing and scaling up investigations need to be beefed-up. A solid heterogeneous catalyst for these processes integrated with continuous processing technology is expected to gain wider acceptance in the future due to its potential effectiveness and efficiency. While there are potential benefits that the solid heterogeneous catalyst can offer, issues related to the low catalytic activity, leachates, reusability and regeneration should be addressed and emphasized in the future research in order to ensure sustainability of the process. The reaction kinetics and also thermodynamic feasibility of glycerol transformation need to be addressed as well.

Other associated matters for the production of value-added chemicals, such as logistic, economic analysis and pilot study, will soon be emerged alongside with the technological investigation.

\section{Perspectives}

Both refined and crude glycerol can be catalytically converted to value-added chemicals. The key issue, though, is the general viability of the process. While numerous reports stated that a good high percentage yield of chemicals was obtained, which was mainly at the lab scale level, it is not guaranteed that a comparable outcome can be obtained. Figure 1 depicts the five crucial issues that must be tackled in order to pursue a more practical catalytic transition of glycerol to value-added chemicals. Each factor is determined by the nature and robustness of the catalyst. A great catalyst with a longer lifetime and reasonable operation is a competitor with a better risk of industrial productivity. The development of this advanced catalyst will guide the production of reactant types, reactor technologies, reaction mechanisms and thermodynamics, as well as the prediction of overall process commercial viability.

\section{Conclusion}

Conversion of glycerol to value added chemicals are still in pursuit for commercial success. Only a few of the available technologies are readily available for commercialization for a few chemicals. There are still huge opportunities for exploration of the catalytic transformation of glycerol to its derivatives. Modelling or simulation of proposed reaction schemes has been scarce. Thus, besides experimentally 
tweaking, testing and optimizing the process, it is essential to study the modelling and simulation aspect as well.

Taking into consideration of the above, more investigations need to be carried out for improvement in the area of robust and effective catalyst (catalysis engineering), reaction engineering and reactor development, reaction kinetics, process optimization, scaling up and pilot plant development in the glycerol transformation to value added chemical context. The tensions in the diminishing price of glycerol market worldwide have amplified more needs to establish convincing routes of obtaining green chemicals. Hence, the transformation of glycerol is seen to be a more sustainable and environmentally friendly process. Therefore, concerted research efforts should be aggressively geared towards it.

\section{Acknowledgments}

The authors would like to thank Universiti Teknologi Malaysia's Collaborative Research Grant (4B485) and Ministry of Higher Education Malaysia (MOHE) for the financial support through Fundamental Research Grant Scheme (FRGS/1/2020/TK0/UTM/02/97).

\section{References}

[1] Luo, X., Ge, X., Cui, S., Li, Y. (2016). Valueadded processing of crude glycerol into chemicals and polymers. Bioresource Technology, $215, \quad 144-154 . \quad$ D O I : 10.1016/j.biortech.2016.03.042.

[2] Bagheri, S., Julkapli, N.M., Yehye, W.A. (2015). Catalytic conversion of biodiesel derived raw glycerol to value added products. Renewable and Sustainable Energy Reviews, 41, 113-127. DOI: 10.1016/j.rser.2014.08.031.

[3] Veluturla, S., Archna, N., Subba Rao, D., Hezil, N., Indraja, I.S., Spoorthi, S. (2018). Catalytic valorization of raw glycerol derived from biodiesel: a review. Biofuels, 9(3), 305-314. DOI: 10.1080/17597269.2016.1266234.

[4] Muraza, O. (2019). Peculiarities of Glycerol Conversion to Chemicals Over Zeolite-Based Catalysts. Frontiers in Chemistry, 7, 233-233. DOI: 10.3389/fchem.2019.00233.

[5] Paillet, F., Marone, A., Moscoviz, R., Steyer, J.-P., Tapia-Venegas, E., Bernet, N., Trably, E. (2019). Improvement of biohydrogen production from glycerol in micro-oxidative environment. International Journal of Hydrogen Energy, 44(33), 17802-17812. DOI: 10.1016/j.ijhydene.2019.05.082.
[6] Abdul Ghani, A., Torabi, F., Ibrahim, H. (2018). Autothermal reforming process for efficient hydrogen production from crude glycerol using nickel supported catalyst: Parametric and statistical analyses. Energy, 144, 129-145. DOI: 10.1016/j.energy.2017.11.132.

[7] Possato, L.G., Chaves, T.F., Cassinelli, W.H., Pulcinelli, S.H., Santilli, C.V., Martins, L. (2017). The multiple benefits of glycerol conversion to acrolein and acrylic acid catalyzed by vanadium oxides supported on micromesoporous MFI zeolites. Catalysis Today, $289, \quad 20-28 . \quad$ D O I : 10.1016/j.cattod.2016.08.005.

[8] Freitas, I.C., Manfro, R.L., Souza, M.M.V.M. (2018). Hydrogenolysis of glycerol to propylene glycol in continuous system without hydrogen addition over $\mathrm{Cu}-\mathrm{Ni}$ catalysts. Applied Catalysis B: Environmental, 220, 31-41. DOI: 10.1016/j.apcatb.2017.08.030.

[9] Ning, X., Li, Y., Yu, H., Peng, F., Wang, H., Yang, Y. (2016). Promoting role of bismuth and antimony on Pt catalysts for the selective oxidation of glycerol to dihydroxyacetone. Journal of Catalysis, 335, 95-104. DOI: 10.1016/j.jcat.2015.12.020.

[10] Marimuthu, M., Marimuthu, P., S.K., A.K., Palanivelu, S., Rajagopalan, V. (2018). Tuning the basicity of $\mathrm{Cu}$-based mixed oxide catalysts towards the efficient conversion of glycerol to glycerol carbonate. Molecular Catalysis, $460, \quad 53-62$. $\quad$ D O I : 10.1016/j.mcat.2018.09.002.

[11] Kong, P.S., Aroua, M.K., Daud, W.M.A.W. (2016). Conversion of crude and pure glycerol into derivatives: A feasibility evaluation. $R e$ newable and Sustainable Energy Reviews, 63, 533-555. DOI: 10.1016/j.rser.2016.05.054.

[12] Nandiwale, K.Y., Patil, S.E., Bokade, V.V. (2014). Glycerol Etherification using nButanol to Produce Oxygenated Additives for Biodiesel Fuel over H-Beta Zeolite Catalysts. Energy Technology, 2(5), 446-452. DOI: 10.1002/ente.201300169.

[13] Zakaria, Z.Y., Amin, N.A.S., Linnekoski, J. Optimization of catalytic glycerol steam reforming to light olefins using Cu/ZSM-5 catalyst. Energy Conversion and Management, 86, $\begin{array}{lllllllllll}7 & 3 & 5 & - & 7 & 4 & 4 & & \mathrm{D} & \mathrm{O} & \mathrm{I}\end{array}$ 10.1016/j.enconman.2014.06.040.

[14] Quispe, C.A.G., Coronado, C.J.R., Carvalho Jr, J.A. (2013). Glycerol: Production, consumption, prices, characterization and new trends in combustion. Renewable and Sustainable Energy Reviews, 27, 475-493. DOI: 10.1016/j.rser.2013.06.017. 
[15] Yeong, S.K., Idris, Z., Hassan, H.A. (2012). 20 - Palm Oleochemicals in Non-food Applications. In O.-M. Lai, C.-P. Tan, C.C. Akoh (Editors), Palm Oil, AOCS Press. p. 587-624.

[16] Tan, H.W., Abdul Aziz, A.R., Aroua, M.K. (2013). Glycerol production and its applications as a raw material: A review. Renewable and Sustainable Energy Reviews, 27, 118-127 DOI: 10.1016/j.rser.2013.06.035.

[17] Ganigué, R., Naert, P., Candry, P., de Smedt, J., Stevens, C.V., Rabaey, K. (2019). Fruity flavors from waste: A novel process to upgrade crude glycerol to ethyl valerate. Bioresource Technology, 289, 121574. DOI: 10.1016/j.biortech.2019.121574.

[18] Helwani, Z., Othman, M.R., Aziz, N., Fernando, W.J.N., Kim, J. (2009). Technologies for production of biodiesel focusing on green catalytic techniques: A review. Fuel Processing Technology, 90(12), 1502-1514. DOI: 10.1016/j.fuproc.2009.07.016.

[19] Zakaria, Z.Y., Amin, N.A.S., Linnekoski, J. (2013). A perspective on catalytic conversion of glycerol to olefins. Biomass and Bioenergy, $55, \quad 370-385 . \quad$ D O I : 10.1016/j.biombioe.2013.02.014.

[20] Ciriminna, R., Della Pina, C., Rossi, M., Pagliaro, M. (2014). Understanding the Glycerol Market. European Journal of Lipid Science and Technology, 116(10), 1432-1439. DOI: $10.1002 /$ jlt.201400229.

[21] Kosamia, N.M., Samavi, M., Uprety, B.K., Rakshit, S.K. (2020). Valorization of Biodiesel Byproduct Crude Glycerol for the Production of Bioenergy and Biochemicals. Catalysts, 10(6), 609. DOI: 10.3390/catal10060609.

[22] Monteiro, M.R., Kugelmeier, C.L., Pinheiro, R.S., Batalha, M.O., da Silva César, A. (2018). Glycerol from biodiesel production: Technological paths for sustainability. Renewable and Sustainable Energy Reviews, 88, 109-122. DOI: 10.1016/j.rser.2018.02.019.

[23] Sarma, S.J., Brar, S.K., Sydney, E.B., Le Bihan, Y., Buelna, G., Soccol, C.R. (2012). Microbial hydrogen production by bioconversion of crude glycerol: A review. International Journal of Hydrogen Energy, 37(8), 64736490. DOI: 10.1016/j.ijhydene.2012.01.050.

[24] Ho Jin, Y., Lee, T., Kim, J.R., Choi, Y.-E., Park, C. (2019). Improved production of bacterial cellulose from waste glycerol through investigation of inhibitory effects of crude glycerol-derived compounds by Gluconacetobacter xylinus. Journal of Industrial and Engineering Chemistry, 75, 158-163. DOI: 10.1016/j.jiec.2019.03.017.
[25] Iyyappan, J., Bharathiraja, B., Baskar, G., Kamalanaban, E. (2019). Process optimization and kinetic analysis of malic acid production from crude glycerol using Aspergillus niger. Bioresource Technology, 281, 18-25. DOI: 10.1016/j.biortech.2019.02.067.

[26] de Paula, F.C., Kakazu, S., de Paula, C.B.C., Gomez, J.G.C., Contiero, J. (2017). Polyhydroxyalkanoate production from crude glycerol by newly isolated Pandoraea sp. Journal of King Saud University - Science, 29(2), 166173. DOI: 10.1016/j.jksus.2016.07.002.

[27] Mangayil, R., Efimova, E., Konttinen, J., Santala, V. (2019). Co-production of 1,3 propanediol and long-chain alkyl esters from crude glycerol. New Biotechnology, 53, 81-89. DOI: 10.1016/j.nbt.2019.07.003.

[28] Badia-Fabregat, M., Rago, L., Baeza, J.A., Guisasola, A. (2019). Hydrogen production from crude glycerol in an alkaline microbial electrolysis cell. International Journal of Hydrogen Energy, 44(32), 17204-17213. DOI: 10.1016/j.ijhydene.2019.03.193.

[29] Kumar, P., Ray, S., Patel, S.K.S., Lee, J.-K., Kalia, V.C. (2015). Bioconversion of crude glycerol to polyhydroxyalkanoate by Bacillus thuringiensis under non-limiting nitrogen conditions. International Journal of Biological Macromolecules, 78, 9-16. DOI: 10.1016/j.ijbiomac.2015.03.046.

[30] Fordham, P., Besson, M., Gallezot, P. (1997). Catalytic oxidation with air of tartronic acid to mesoxalic acid on bismuth-promoted platinum. Catalysis Letters, 46(3-4), 195-199. DOI: 10.1023/A:1019082905366.

[31] Fordham, P., Garcia, R., Besson, M., Gallezot, P. (1996). Selective catalytic oxidation with air of glycerol and oxygenated derivatives on platinum metals. In J.W. Hightower, W.N. Delgass, E. Iglesia, A.T. Bell (Editors) Studies in Surface Science and Catalysis, Elsevier. p. 161-170.

[32] Fordham, P., Besson, M., Gallezot, P. (1995). Selective catalytic oxidation of glyceric acid to tartronic and hydroxypyruvic acids. Applied Catalysis A: General, 133(2), L179-L184. DOI: 10.1016/0926-860X(95)00254-5.

[33] Abbadi, A., van Bekkum, H. (1996). Selective chemo-catalytic routes for the preparation of B-hydroxypyruvic acid. Applied Catalysis A: General, 148(1), 113-122. DOI: 10.1016/S0926-860X(96)00229-3.

[34] Abro, S., Pouilloux, Y., Barrault, J. (1997). Selective synthesis of monoglycerides from glycerol and oleic acid in the presence of solid catalysts. In H.U. Blaser, A. Baiker, R. Prins, (Editors) Studies in Surface Science and $\mathrm{Ca}$ talysis. Elsevier. p. 539-546. 
[35] Vieville, C., Yoo, J.W., Pelet, S., Mouloungui, Z. (1998). Synthesis of glycerol carbonate by direct carbonatation of glycerol in supercritical $\mathrm{CO}_{2}$ in the presence of zeolites and ion exchange resins. Catalysis Letters, 56(4), 245247. DOI: $10.1023 / \mathrm{A} \% 3 \mathrm{~A} 1019050205502$

[36] Qing, Y., Lu, H., Liu, Y., Liu, C., Liang, B., Jiang, W. (2018). Production of glycerol carbonate using crude glycerol from biodiesel production with DBU as a catalyst. Chinese Journal of Chemical Engineering, 26(9), 19121919. DOI: 10.1016/j.cjche.2018.01.010.

[37] Sonnati, M.O., Amigoni, S., Taffin de Givenchy, E.P., Darmanin, T., Choulet, O., Guittard, F. (2013). Glycerol carbonate as a versatile building block for tomorrow: synthesis, reactivity, properties and applications. Green Chemistry, 15(2), 283-306. DOI: 10.1039/C2GC36525A.

[38] Carrettin, S., McMorn, P., Johnston, P., Griffin, K., Hutchings, G.J. (2002). Selective oxidation of glycerol to glyceric acid using a gold catalyst in aqueous sodium hydroxide. Chemical Communications, 2002(7), 696-697. DOI: 10.1039/B201112N.

[39] Teng, W.K., Ngoh, G.C., Yusoff, R., Aroua, M.K. (2016). Microwave-assisted transesterification of industrial grade crude glycerol for the production of glycerol carbonate. Chemical Engineering Journal, 284, 469-477. DOI: 10.1016/j.cej.2015.08.108.

[40] Mahdi, H.I., Irawan, E., Nuryoto, N., Jayanudin, J., Sulistyo, H., Sediawan, W.B., Muraza, O. (2016). Glycerol carbonate production from biodiesel waste over modified natural clinoptilolite. Waste and Biomass Valorization, 7(6), 1349-1356. DOI: 10.1007/s12649016-9495-3.

[41] Liu, J., Li, Y., Liu, H., He, D. (2019). Photothermal synergistically catalytic conversion of glycerol and carbon dioxide to glycerol carbonate over Au/ZnWO4-ZnO catalysts. Applied Catalysis B: Environmental, 244, 836843. DOI: 10.1016/j.apcatb.2018.12.018.

[42] Hoang, T.Q., Zhu, X., Danuthai, T., Lobban, L.L., Resasco, D.E., Mallinson, R.G. (2010). Conversion of Glycerol to Alkyl-aromatics over Zeolites. Energy \& Fuels, 24(7), 38043809. DOI: 10.1021/ef100160y.

[43] Weyda, H., Köhler, E. (2003). 8 Modern refining concepts-an update on naphthaisomerization to modern gasoline manufacture. In M. Anpo, M. Onaka, H. Yamashita (Editors) Studies in Surface Science and $\mathrm{Ca}$ talysis. Elsevier. p. 61-66.
[44] Al-Kinany, M.C., Al-Khowaiter, S.H., AlMalki, F.H. (2001). Synthesis of Cumene (Isopropylbenzene) from Diisopropylbenzenes in the presence of Benzene using Triflic acid as catalyst at room temperature. In G.F. Froment, K.C. Waugh (Editors) Studies in Surface Science and Catalysis, Elsevier. p. 459464.

[45] Ghosh, P., Hickey, K.J., Jaffe, S.B. (2006). Development of a Detailed Gasoline Composition-Based Octane Model. Industrial \& Engineering Chemistry Research, 45(1), 337-345. DOI: 10.1021/ie050811h.

[46] Niziolek, A.M., Onel, O., Guzman, Y.A., Floudas, C.A. (2016) Biomass-Based Production of Benzene, Toluene, and Xylenes via Methanol: Process Synthesis and Deterministic Global Optimization. Energy \& Fuels, 30 ( 6 ), $\quad 4970-4998$. D O I : 10.1021/acs.energyfuels.6b00619

[47] Tarasov, A.L. (2018). Catalytic Conversion of Glycerol into Aromatic Hydrocarbons, Acrolein, and Glycerol Ethers on Zeolite Catalysts. Russian Journal of Physical Chemistry A, 92, $\begin{array}{llllllllllllll}2 & 4 & 5 & 1 & - & 2 & 4 & 5 & 4 & \text {. } & & \text { D } & \text { O } & \text { I : }\end{array}$ 10.1134/S0036024418120397.

[48] Wang, F., Xiao, W., Gao, L., Xiao, G. (2016). Enhanced performance of glycerol to aromatics over Sn-containing HZSM-5 zeolites. RSC Advances, 6(49), 42984-42993. DOI: 10.1039/C6RA03358J.

[49] Wang, F., Chu, X., Zhu, F., Wu, F., Li, Q., Liu, B., Xiao, G. (2019). Producing BTX aromatics-enriched oil from biomass derived glycerol using dealuminated HZSM-5 by successive steaming and acid leaching as catalyst: Reactivity, acidity and product distribution. Microporous and Mesoporous Materials, $277, \quad 286-294 . \quad$ D O I : 10.1016/j.micromeso.2018.11.015.

[50] Wang, F., Zhou, M.-x., Yang, X.-h., Gao, L.-j., Xiao, G.-m. (2017). The effect of hierarchical pore architecture on one-step catalytic aromatization of glycerol: Reaction routes and catalytic performances. Molecular Catalysis, 432, 144-154. DOI: 10.1016/j.mcat.2017.01.017.

[51] Yang, X., Wang, F., Wei, R., Li, S., Wu, Y., Shen, P., Wang, H., Gao, L., Xiao, G. (2018). Synergy effect between hierarchical structured and Sn-modified H[Sn,Al]ZSM-5 zeolites on the catalysts for glycerol aromatization. Microporous and Mesoporous Materials, $257, \quad 154-161$. D O I : 10.1016/j.micromeso.2017.08.039.

[52] He, S., Muizebelt, I., Heeres, A., Schenk, N.J., Blees, R., Heeres, H.J. (2018). Catalytic pyrolysis of crude glycerol over shaped ZSM5/bentonite catalysts for bio-BTX synthesis. Applied Catalysis B: Environmental, 235, 4555. DOI: 10.1016/j.apcatb.2018.04.047. 
[53] Murata, K., Takahara, I., Inaba, M. (2008). Propane formation by aqueous-phase reforming of glycerol over Pt/H-ZSM5 catalysts. Reaction Kinetics and Catalysis Letters, 93(1), 59-66. DOI: 10.1007/s11144-008-5190-0.

[54] Zakaria, Z.Y., Linnekoski, J., Amin, N.A.S. (2012). Catalyst screening for conversion of glycerol to light olefins. Chemical Engineering Journal, 207-208, 803-813. DOI: 10.1016/j.cej.2012.07.072.

[55] Wu, Z., Yan, H., Ge, S., Gao, J., Dou, T., Li, Y., Yip, A.C.K., Zhang, M. (2017). MoO3 modified Ni2P/Al2O3 as an efficient catalyst for crude glycerol to propylene. Catalysis Communications, $92, \quad 80-85$. DOI: 10.1016/j.catcom.2017.01.009.

[56] Mandal, S., Mandal, S., Ghosh, S.K., Sar, P., Ghosh, A., Saha, R., Saha, (2016). A review on the advancement of ether synthesis from organic solvent to water. RSC Advances, 6(73), 69605-69614. DOI: 10.1039/C6RA12914E.

[57] Roze, M., Kampars, V., Teivena, K., Kampare, R., Liepins, E. (2013). Catalytic Etherification of Glycerol with Alcohols. Material Science and Applied Chemistry, 28, 67. DOI: 10.7250/msac.2013.011.

[58] Gonzalez-Arellano, C., Grau-Atienza, A., Serrano, E., Romero, A.A., Garcia-Martinez, J., Luque, R. (2015). The role of mesoporosity and $\mathrm{Si} / \mathrm{Al}$ ratio in the catalytic etherification of glycerol with benzyl alcohol using ZSM-5 zeolites. Journal of Molecular Catalysis A: Chemical, 406, 40-45. DOI: 10.1016/j.molcata.2015.05.011.

[59] Kowalska-Kus, J., Held, A., Frankowski, M., Nowinska, K. (2017). Solketal formation from glycerol and acetone over hierarchical zeolites of different structure as catalysts. Journal of Molecular Catalysis A: Chemical, 426, 205212. DOI: 10.1016/j.molcata.2016.11.018.

[60] Bivona, L.A., Vivian, A., Fusaro, L., Fiorilli, S., Aprile, C. (2019). Design and catalytic applications of 1D tubular nanostructures: Improving efficiency in glycerol conversion. Applied Catalysis B: Environmental, 247, 182190. DOI: 10.1016/j.apcatb.2019.01.085.

[61] Manjunathan, P., Maradur, S.P., Halgeri, A.B., Shanbhag, G.V. (2015). Room temperature synthesis of solketal from acetalization of glycerol with acetone: Effect of crystallite size and the role of acidity of beta zeolite. Journal of Molecular Catalysis A: Chemical, 396, 4754. DOI: 10.1016/j.molcata.2014.09.028.

[62] López, A., Aragón, J.A., Hernández-Cortez, J.G., Mosqueira, M.L., Martínez-Palou, R. (2019). Study of hydrotalcite-supported transition metals as catalysts for crude glycerol hydrogenolysis. Molecular Catalysis, 468, 918. DOI: 10.1016/j.mcat.2019.02.008.
[63] Veiga, S., Bussi, J. (2017). Steam reforming of crude glycerol over nickel supported on activated carbon. Energy Conversion and Mana gement, $141, \quad 79-84$. D O I : 10.1016/j.enconman.2016.04.103.

[64] Veiga, S., Faccio, R., Segobia, D., Apesteguía, C., Bussi, J. (2017). Hydrogen production by crude glycerol steam reforming over $\mathrm{Ni}-\mathrm{La}-$ Ti mixed oxide catalysts. International Journal of Hydrogen Energy, 42(52), 30525-30534. DOI: $10.1016 /$ j.ijhydene.2017.10.118.

[65] Ribao, P., Alexandra Esteves, M., Fernandes, V.R., Rivero, M.J., Rangel, C.M., Ortiz, I. (2018). Challenges arising from the use of $\mathrm{TiO} 2 / \mathrm{rGO} / \mathrm{Pt}$ photocatalysts to produce hydrogen from crude glycerol compared to synthetic glycerol. International Journal of Hydrogen Energy, 44(53), 28494-28506. DOI: 10.1016/j.ijhydene.2018.09.148.

[66] Hu, S., Li, Y. (2014). Polyols and polyurethane foams from base-catalyzed liquefaction of lignocellulosic biomass by crude glycerol: Effects of crude glycerol impurities. Industrial Crops and Products, 57, 188-194. DOI: 10.1016/j.indcrop.2014.03.032.

[67] Analyst, P.I. (2009). Linde Group develops sustainable hydrogen production process. Pump Industry Analyst, 2009(5), 2. DOI: 10.1016/S1359-6128(09)70172-7.

[68] Voegele, E. (2012). Linde's glycerin-based hydrogen achieves certification. In Biodiesel Magazine. BBI International.

[69] kvt.technology. (2019). Epichlorohydrin production. Available from : http://www.kvt.technology/en/technologies/pr oduction-technologies/epiprovit.html.

[70] Nomanbhay, S., Hussein, R., Ong, M.Y. (2018). Sustainability of biodiesel production in Malaysia by production of bio-oil from crude glycerol using microwave pyrolysis: a review. Green Chemistry Letters and Reviews, 11 ( 2 ), $\quad 135-157$. D O I : 10.1080/17518253.2018.1444795.

[71] Almeida, A., Ribeiro, A., Ramalho, E., Pilão, R. (2018). Crude glycerol gasification in a fixed bed gasifier. Energy Procedia, 153, 149153. DOI: 10.1016/j.egypro.2018.10.060.

[72] Tamošiūnas, A., Gimžauskaitè, D., Uscila, R., Aikas, M. (2019). Thermal arc plasma gasification of waste glycerol to syngas. Applied Energy, $251, \quad 113306$. D O : 10.1016/j.apenergy.2019.113306.

[73] Manara, P., Zabaniotou, A. (2013). Copyrolysis of biodiesel-derived glycerol with Greek lignite: A laboratory study. Journal of Analytical and Applied Pyrolysis, 100, 166172. DOI: 10.1016/j.jaap.2012.12.013. 
[74] Ganesapillai, M., Manara, P., Zabaniotou, A. (2016). Effect of microwave pretreatment on pyrolysis of crude glycerol-olive kernel alternative fuels. Energy Conversion and Management, $110, \quad 287-295$. D O I : 10.1016/j.enconman.2015.12.045.

[75] Ye, X.P., Ren, S. (2014). Value-Added Chemicals from Glycerol. In Soy-Based Chemicals and Materials. American Chemical Society. p. 43-80.

[76] Wang, Y., Xiao, Y., Xiao, G. (2019). Sustainable value-added C3 chemicals from glycerol transformations: A mini review for heterogeneous catalytic processes. Chinese Journal of Chemical Engineering, 27(7), 1536-1542. DOI: 10.1016/j.cjche.2019.03.001.

[77] Corma, A., Huber, G.W., Sauvanaud, L., O'Connor, P. (2008). Biomass to chemicals: Catalytic conversion of glycerol/water mixtures into acrolein, reaction network. Journal of Catalysis, 257(1), 163-171. DOI: 10.1016/j.jcat.2008.04.016.

[78] Zaidi, H.A., Pant, K.K. (2005). Catalytic activity of copper oxide impregnated HZSM-5 in methanol conversion to liquid hydrocarbons. Canadian Journal of Chemical Engineering, 83(6), 970-977. 10.1002/cjce.5450830606

[79] Pompeo, F., Santori, G., Nichio, N.N. (2010). Hydrogen and/or syngas from steam reforming of glycerol. Study of platinum catalysts. International Journal of Hydrogen Energy, $35(17)$, $8912-8920$. D O I : 10.1016/j.ijhydene.2010.06.011.

[80] Calleja, G., Botas, J.A., Sánchez-Sánchez, M., Orcajo, M.G. (2010). Hydrogen adsorption over Zeolite-like MOF materials modified by ion exchange. International Journal of Hydrogen Energy, 35(18), 9916-9923. DOI: 10.1016/j.ijhydene.2010.02.114.

[81] Zakaria, Z.Y., Jusoh, M., Johari, A., Abdullah, T.A.T., Hassim, M.H., Kidam, K., Kamaruddin, M.J., Sulaiman, W.R.W. (2015). Thermodynamic Analysis of Hydrogen Production from Ethanol-glycerol Mixture through Steam and Dry Reforming. Procedia Manufacturing, 2, 92-96. DOI: 10.1016/j.promfg.2015.07.016.

[82] Jusoh, M., Yahya, N., Farhana, N., Zakaria, Z.Y. (2016). Thermodynamic Analysis of Glycerol Dry Reforming to Hydrogen at Low Pressure. In Conference Proceedings Fourth International Conference on Advances in BioInformatics, Bio-Technology and Environmental Engineering - ABBE 2016, 37-41. Birmingham City University (City North Campus), Perry Barr, Birmingham B42 2SU, UK. DOI: 10.15224/978-1-63248-091-0-09.
[83] Zakaria, Z.Y., Amin, N.A.S., Linnekoski, J. (2014). Thermodynamic Analysis of Glycerol Conversion to Olefins. Energy Procedia, 61,

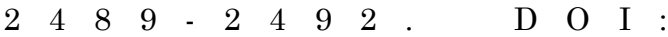
10.1016/j.egypro.2014.12.029.

[84] Ali, O.M., Mamat, R., Rasul, M.G., Najafi, G. (2017). Chapter Eighteen - Potential of Biodiesel as Fuel for Diesel Engine. In M.G. Rasul, A.k. Azad, S.C. Sharma (Editors) Clean Energy for Sustainable Development. Academic Press. p. 557-590.

[85] Swaminathan, M. (2018). Chapter 10 - Semiconductor Oxide Nanomaterials as Catalysts for Multiple Applications. In C. Mustansar Hussain (Editor) Handbook of Nanomaterials for Industrial Applications. Elsevier. p. 197207.

[86] Bruemmer, M. (1999). PTFE-lined equipment (columns and vessels) for the chemical process industry. Advantages/disadvantages of paste-extruded PTFE. In Corrosion 1999 conference. San Antonio, TX (United States).

[87] Galadima, A., Muraza, O. (2016). A review on glycerol valorization to acrolein over solid acid catalysts. Journal of the Taiwan Institute of Chemical Engineers, 67, 29-44. DOI: 10.1016/j.jtice.2016.07.019.

[88] Adhikari, S., Fernando, S., Gwaltney, S.R., Filip To, S.D., Bricka, R.M., Steele, P.H., Haryanto, A. (2007). A thermodynamic analysis of hydrogen production by steam reforming of glycerol. International Journal of $\mathrm{Hy}$ drogen Energy, 32(14), 2875-2880. DOI: 10.1016/j.ijhydene.2007.03.023.

[89] Cheng, C.K., Foo, S.Y., Adesina, A.A. (2012). Thermodynamic analysis of glycerol-steam reforming in the presence of $\mathrm{CO}_{2}$ or $\mathrm{H}_{2}$ as carbon gasifying agent. International Journal of Hydrogen Energy, 37(13), 10101-10110. DOI: 10.1016/j.ijhydene.2012.04.005.

[90] Kale, G.R., Kulkarni, B.D. (2010). Thermodynamic analysis of dry autothermal reforming of glycerol. Fuel Processing Technology, 91(5), 520-530. DOI: 10.1016/j.fuproc.2009.12.015.

[91] Alvarado, F.D., Gracia, F. (2012). Oxidative steam reforming of glycerol for hydrogen production: Thermodynamic analysis including different carbon deposits representation and $\mathrm{CO} 2$ adsorption. International Journal of $\mathrm{Hy}$ drogen Energy, 37(19), 14820-14830. DOI: 10.1016/j.ijhydene.2012.01.158.

[92] Aghbashlo, M., Hosseinpour, S., Tabatabaei, M., Rastegari, H., Ghaziaskar, H.S. (2019). Multi-objective exergoeconomic and exergoenvironmental optimization of continuous synthesis of solketal through glycerol ketalization with acetone in the presence of ethanol as co-solvent. Renewable Energy, 130, 735748. DOI: 10.1016/j.renene.2018.06.103. 
[93] Maglinao, R.L., He, B.B. (2011). Catalytic Thermochemical Conversion of Glycerol to Simple and Polyhydric Alcohols Using Raney Nickel Catalyst. Industrial \& Engineering Chemistry Research, 50(10), 6028-6033. DOI: 10.1021/ie102573m.

[94] Checa, M., Nogales-Delgado, S., Montes, V., Encinar, J.M. (2020). Recent Advances in Glycerol Catalytic Valorization: A Review. Catalysts, 10(11), 1279. DOI: $10.3390 /$ catal10111279.

[95] Liu, J., Jiang, Y., Zhang, P., Yang, B. (2021). Enhance glycerol conversion through coetherification with isobutene and tertbutanol. Fuel Processing Technology, 218, 106838. DOI: 10.1016/j.fuproc.2021.106838.

[96] Imbault, A.L., Gong, J., Farnood, R. (2020). Photocatalytic production of dihydroxyacetone from glycerol on $\mathrm{TiO}_{2}$ in acetonitrile. $R S C A d$ vances, 10(9), 4956-4968. DOI: 10.1039/C9RA09434B.

[97] Kostyniuk, A., Bajec, D., Djinović, P., Likozar, B. (2020). Allyl alcohol production by gas phase conversion reactions of glycerol over bifunctional hierarchical zeolite-supported biand tri-metallic catalysts. Chemical Engineering Journal, 397, 125430. DOI: 10.1016/j.cej.2020.125430.

[98] Talebian-Kiakalaieh, A., Tarighi, S. (2019). Hierarchical faujasite zeolite-supported heteropoly acid catalyst for acetalization of crudeglycerol to fuel additives. Journal of Industrial and Engineering Chemistry, 79, 452-464. DOI: 10.1016/j.jiec.2019.07.021.

[99] Dou, B., Song, Y., Wang, C., Chen, H., Xu, Y. (2014). Hydrogen production from catalytic steam reforming of biodiesel byproduct glycerol: Issues and challenges. Renewable and Sustainable Energy Reviews, 30, 950-960. DOI: 10.1016/j.rser.2013.11.029.

[100] Laino, T., Tuma, C., Curioni, A., Jochnowitz, E., Stolz, S. (2011). A Revisited Picture of the Mechanism of Glycerol Dehydration. The Journal of Physical Chemistry A, 115(15), 3592-3595. DOI: 10.1021/jp201078e.

[101] Yuan, Z., Gao, Z., Xu, B.-Q. (2015). Acid-base property of the supporting material controls the selectivity of Au catalyst for glycerol oxidation in base-free water. Chinese Journal of Catalysis, 36(9), 1543-1551. DOI: 10.1016/S1872-2067(15)60936-6.

[102] National Center for Biotechnology Information (17 August 2019). PubChem Compound Summary for CID 751, Glyceraldehyde.

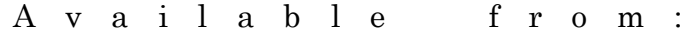
https://pubchem.ncbi.nlm.nih.gov/compound/ Glyceraldehyde
[103] Li, S., Deng, W., Li, Y., Zhang, Q., Wang, Y. (2019). Catalytic conversion of cellulose-based biomass and glycerol to lactic acid. Journal of Energy Chemistry, 32, 138-151. DOI: 10.1016/j.jechem.2018.07.012.

[104] Razali, N., Abdullah, A.Z. (2017). Production of lactic acid from glycerol via chemical conversion using solid catalyst: A review. $A p$ plied Catalysis A: General, 543, 234-246. DOI: 10.1016/j.apcata.2017.07.002.

[105] Zhang, C., Wang, T., Liu, X., Ding, Y. (2016). $\mathrm{Cu}$-promoted Pt/activated carbon catalyst for glycerol oxidation to lactic acid. Journal of Molecular Catalysis A: Chemical, 424, 91-97. DOI: 10.1016/j.molcata.2016.08.018.

[106] Fernandes, A., Filipa Ribeiro, M., Lourenço, J.P. (2017). Gas-phase dehydration of glycerol over hierarchical silicoaluminophosphate SAPO-40. Catalysis Communications, 95, 1620. DOI: 10.1016/j.catcom.2017.02.015.

[107] Carriço, C.S., Cruz, F.T., dos Santos, M.B., Oliveira, D.S., Pastore, H.O., Andrade, H.M.C., Mascarenhas, A.J.S. (2016). MWWtype catalysts for gas phase glycerol dehydration to acrolein. Journal of Catalysis, 334, 3441. DOI: 10.1016/j.jcat.2015.11.010.

[108] Deleplanque, J., Dubois, J.L., Devaux, J.F., Ueda, W. (2010). Production of acrolein and acrylic acid through dehydration and oxydehydration of glycerol with mixed oxide catalysts. Catalysis Today, 157(1-4), 351-358. DOI: 10.1016/j.cattod.2010.04.012.

[109] Liu, S., Tamura, M., Shen, Z., Zhang, Y., Nakagawa, Y., Tomishige, K. (2018). Hydrogenolysis of glycerol with in-situ produced H2 by aqueous-phase reforming of glycerol using Pt-modified $\mathrm{Ir}-\mathrm{ReOx} / \mathrm{SiO} 2$ catalyst. Catalysis Today, 303, 106-116. DO I : 10.1016/j.cattod.2017.07.025.

[110] Sun, D., Yamada, Y., Sato, S., Ueda, W. (2016). Glycerol hydrogenolysis into useful C3 chemicals. Applied Catalysis B: Environment a l, $193, \quad 75-92$. D O I : 10.1016/j.apcatb.2016.04.013.

[111] Gandarias, I., Arias, P.L., Requies, J., Güemez, M.B., Fierro, J.L.G. (2010). Hydrogenolysis of glycerol to propanediols over a Pt/ASA catalyst: The role of acid and metal sites on product selectivity and the reaction mechanism. Applied Catalysis B: Environmental, $\quad 97(1), \quad 248-256$. DOI: 10.1016/j.apcatb.2010.04.008.

[112] Sullivan, C.J., Kuenz, A., Vorlop, K.-D. (2018). Propanediols. In Ullmann's Encyclopedia of Industrial Chemistry. Wiley-VCH Verlag GmbH \& Co. KGaA. p. 1-15. DOI: 10.1002/14356007.a22_163.pub2. 
[113] Zhou, C.H., Zhao, H., Tong, D.S., Wu, L.M., Yu, W.H. (2013). Recent Advances in Catalytic Conversion of Glycerol. Catalysis Reviews, $55(4), \quad 369-453$. D O I : $10.1080 / 01614940.2013 .816610$.

[114] marketresearchstore.com. Global Epichlorohydrin Market Is Set for Rapid Growth, To Reach Around 2,262.8 Kilo Tons By 2020. 20166 April 2016; Available from: https://www.marketresearchstore.com/news/gl obal-epichlorohydrin-market-206.

[115] Cui, S., Borgemenke, J., Liu, Z., Keener, H.M., Li, Y. (2019). Innovative sustainable conversion from $\mathrm{CO}_{2}$ and biodiesel-based crude glycerol waste to bio-based polycarbonates. Journal of CO2 Utilization, 34, 198206. DOI: 10.1016/j.jcou.2019.06.004.

[116] Galadima, A., Muraza, O. (2017). Sustainable Production of Glycerol Carbonate from Byproduct in Biodiesel Plant. Waste and Biomass Valorization, 8(1), 141-152. DOI: 10.1007/s12649-016-9560-y.

[117] Hunsom, M., Saila, P. (2015). Electrochemical conversion of enriched crude glycerol: Effect of operating parameters. Renewable Energy, $74, \quad 227-236$. D O I : 10.1016/j.renene.2014.08.008.

[118] Zhang, C., Wang, T., Ding, Y. (2017). Onestep synthesis of pyruvic acid from glycerol oxidation over $\mathrm{Pb}$ promoted Pt/activated carbon catalysts. Chinese Journal of Catalysis, 38, 928-937. DOI: 10.1016/S18722067(17)62835-3.
[119] Tshibalonza, N.N., Monbaliu, J.-C.M. (2017). Revisiting the deoxydehydration of glycerol towards allyl alcohol under continuous-flow conditions. Green Chemistry, 19(13), 30063013. DOI: 10.1039/C7GC00657H.

[120] Qadariyah, L., Mahfud, M., Sumarno, S., Machmudah, S., Wahyudiono, W., Sasaki, M., Goto, M. (2011). Degradation of glycerol using hydrothermal process. Bioresource Technology, $102(19), \quad 9267-9271$. DOI: 10.1016/j.biortech.2011.06.066.

[121] Blass, S.D., Hermann, R.J., Persson, N.E., Bhan, A., Schmidt, L.D. (2014). Conversion of glycerol to light olefins and gasoline precursors. Applied Catalysis A: General, 475, 1015. DOI: $10.1016 /$ j.apcata.2014.01.013.

[122] Karinen, R.S., Krause, A.O.I. (2006). New biocomponents from glycerol. Applied Catalysis A: General, 306, 128-133. DOI: 10.1016/j.apcata.2006.03.047.

[123] Kostyniuk, A., Bajec, D., Djinović, P., Likozar, B. (2020). Allyl alcohol production by gas phase conversion reactions of glycerol over bifunctional hierarchical zeolitesupported bi- and tri-metallic catalysts Author links open overlay, Chemical Engineering Journal, 397, 125430. DOI: 10.1016/j.cej.2020.125430

Selected and Revised Papers from International Conference on Sustainable Energy and Catalysis 2021 (ICSEC 2021) (https://engineering.utm.my/chemicalenergy/icsec2021/) (School of Chemical and Energy Engineering, Faculty of Engineering, Universiti Teknologi Malaysia, 16-17th February 2021) after Peer-reviewed by Scientific Committee of ICSEC 2021 and Peer-Reviewers of Bulletin of Chemical Reaction Engineering \& Catalysis.

Editors (Guest) in this ICSEC 2021 section are Nor Aishah Saidina Amin, Mohd Asmadi Mohammed Yussuf, Salman Raza Naqui, while Editor in Chief is I. Istadi. 